\title{
Insights from low-temperature thermochronometry into transpressional deformation and crustal exhumation along the San Andreas fault in the western Transverse Ranges, California
}

\author{
Nathan A. Niemi, ${ }^{1}$ Jamie T. Buscher, ${ }^{2}$ James A. Spotila, ${ }^{3}$ Martha A. House, ${ }^{4}$ \\ and Shari A. Kelley ${ }^{5}$ \\ Received 21 May 2013; revised 21 October 2013; accepted 28 October 2013; published 20 December 2013.
}

[1] The San Emigdio Mountains are an example of an archetypical, transpressional structural system, bounded to the south by the San Andreas strike-slip fault, and to the north by the active Wheeler Ridge thrust. Apatite (U-Th)/He and apatite and zircon fission track ages were obtained along transects across the range and from wells in and to the north of the range. Apatite (U-Th)/He ages are 4-6 Ma adjacent to the San Andreas fault, and both (U-Th)/He and fission track ages grow older with distance to the north from the San Andreas. The young ages north of the San Andreas fault contrast with early Miocene (U-Th)/He ages from Mount Pinos on the south side of the fault. Restoration of sample paleodepths in the San Emigdio Mountains using a regional unconformity at the base of the Eocene Tejon Formation indicates that the San Emigdio Mountains represent a crustal fragment that has been exhumed more than $5 \mathrm{~km}$ along the San Andreas fault since late Miocene time. Marked differences in the timing and rate of exhumation between the northern and southern sides of the San Andreas fault are difficult to reconcile with existing structural models of the western Transverse Ranges as a thin-skinned thrust system. Instead, these results suggest that rheologic heterogeneities may play a role in localizing deformation along the Big Bend of the San Andreas fault as the San Emigdio Mountains are compressed between the crystalline basement of Mount Pinos and oceanic crust that underlies the southern San Joaquin Valley.

Citation: Niemi, N. A., J. T. Buscher, J. A. Spotila, M. A. House, and S. A. Kelley (2013), Insights from low-temperature thermochronometry into transpressional deformation and crustal exhumation along the San Andreas fault in the western Transverse Ranges, California, Tectonics, 32, 1602-1622, doi:10.1002/2013TC003377.

\section{Introduction}

[2] Spatial and temporal changes in plate boundary deformation are reflective of the complex relationship between the deep lithosphere and brittle upper crust [Molnar, 1988; Bourne et al., 1998]. At transpressive plate margins, rugged mountain chains can straddle the main fault trace, suggesting

\footnotetext{
Additional supporting information may be found in the online version of this article.

${ }^{1}$ Department of Earth and Environmental Sciences, University of Michigan, Ann Arbor, Michigan, USA.

${ }^{2}$ Dipartimento di Scienze della Terra, dell'Ambiente e delle Risorse, Università di Napoli Federico II, Napoli, Italy.

${ }^{3}$ Department of Geosciences, Virginia Polytechnic Institute and State University, Blacksburg, Virginia, USA.

${ }^{4}$ Natural Sciences Division, Pasadena City College, Pasadena, California, USA.

${ }^{5}$ Department of Earth and Environmental Science, New Mexico Institute of Mining and Technology, Socorro, New Mexico, USA.

Corresponding author: N. A. Niemi, Department of Earth and Environmental Sciences, University of Michigan, 2534 C. C. Little Bldg., 1100 N. University Ave., Ann Arbor, MI 48109-1005, USA. (naniemi@umich.edu)

(C)2013. American Geophysical Union. All Rights Reserved. 0278-7407/13/10.1002/2013TC003377
}

that a direct correlation exists between oblique plate motion and tectonic deformation [Sanderson and Marchini, 1984; Teyssier et al., 1995]. Surface features including en echelon folds, flower structures, and pop-ups found less than $20 \mathrm{~km}$ from the main fault strand (i.e., near field) are believed to reflect upper crustal shortening from fault geometry variations [Sylvester, 1988; Bürgmann, 1991; Vauchez and Nicolas, 1991]. Analog and numerical models illustrate that contractional strain scales with convergence, with plate motion obliquities $>20^{\circ}$ generating significant near-field uppercrustal shortening [Wilcox et al., 1973; Odonne and Vialon, 1983; Tikoff and Teyssier, 1994; Dewey et al., 1998; Fossen and Tikoff, 1998], while thermochronometry studies of active orogens demonstrate that rapid exhumation can be focused along tranpressional fault zones with high plate obliquity [e.g., Fitzgerald et al., 1993; Tippett and Kamp, 1993; Foster et al., 1994; Spotila et al., 2001; Thomson, 2002]. Despite this broad understanding of the relationship between plate obliquity and near-field crustal deformation, a detailed understanding of the spatial and temporal distribution of crustal deformation along transpressive plate boundaries is often obscured by complex fault geometries and translation along strike-slip fault zones [Spotila et al., 2007b, 2007a]. For example, strike-slip fault bends that are typified 

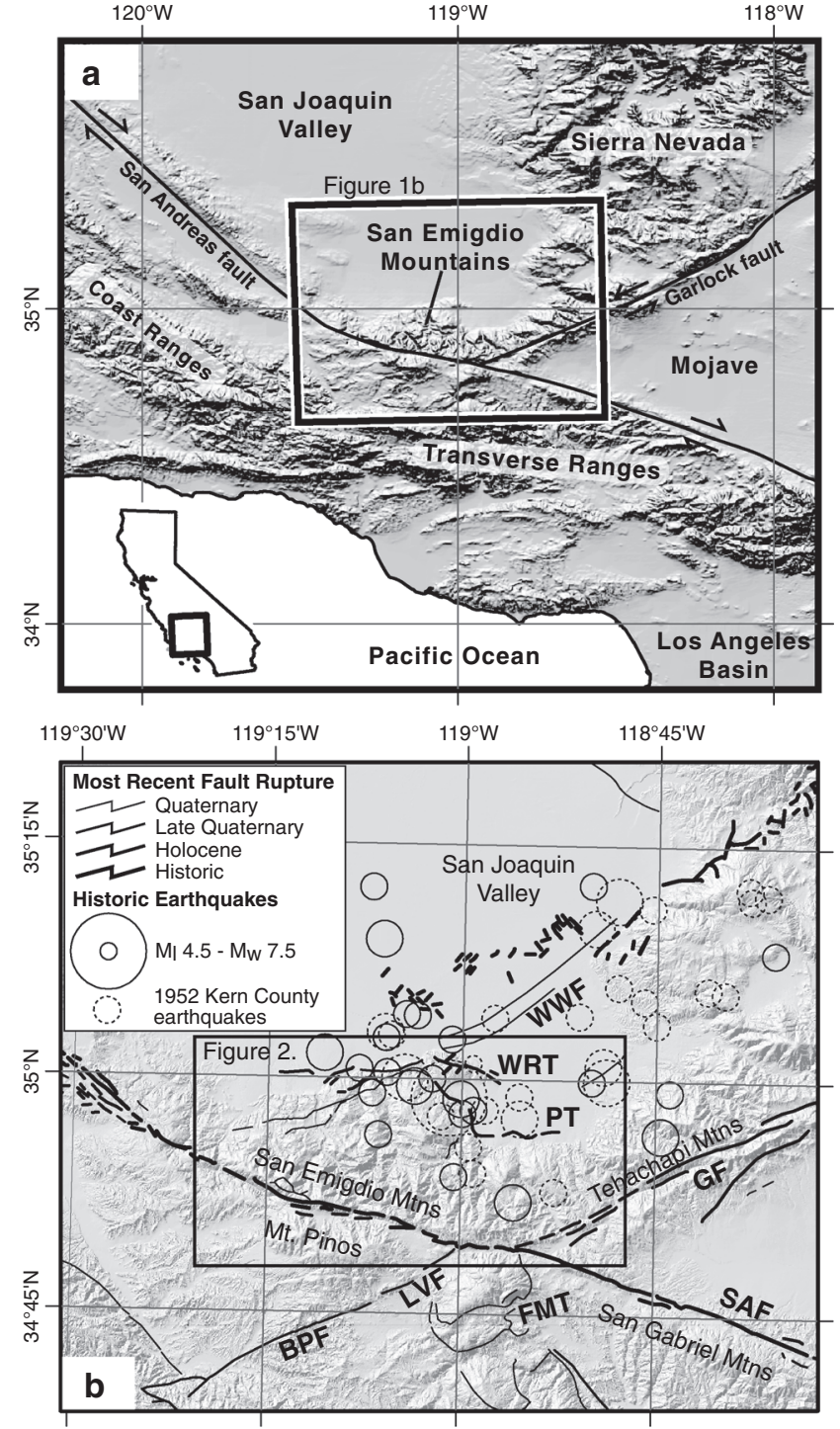

Figure 1. (a) The San Emigdio Mountains lie at the western end of the Big Bend of the San Andreas fault, at the southern end of the San Joaquin Valley, just west of the intersection of the San Andreas and the Garlock faults. These mountains are considered part of the western Transverse Ranges (WTR), but are the only mountain range in the WTR attached to the North American plate. (b) Map of historic recorded earthquakes [Hutton et al., 2010] and recently active faults [Jennings, 1994; Dart et al., 2000] in the vicinity of the San Emigdio Mountains. Dashed circles are earthquakes associated with the $1952 M_{w} 7.5$ Kern County earthquake. Abbreviations for faults are BPF, Big Pine fault; FMT, Frazier Mountain thrust; GF, Garlock fault; LVF, Lockwood Valley fault; PT, Pleito thrust; SAF, San Andreas fault; WRT, Wheeler Ridge thrust; and WWF, White Wolf fault.

by near-field mountainous terrain can have maximum topography away from highly contractional fault corners, suggesting that deformation is variable along strike [Anderson, 1990; Bourne et al., 1998; Teyssier et al., 2002]. Crustal shortening found at fault bends can also be transient, ultimately leading to the propagation of new fault strands and the migration of step over faults [Wakabayashi et al., 2004], and thus crustal slivers found adjacent to strike-slip fault zones can be in the erosional downwearing stage of mountain building despite a rugged appearance, having translated away from the active uplift zone [e.g., Buscher and Spotila, 2007].

[3] The primary driver of crustal strain and subsequent topographic response along strike-slip faults is yet to be unambiguously assigned to a unique tectonic process. Some authors suggest that the evolution of transform fault zones is controlled by the interplate strength of the main fault strand [e.g., Mount and Suppe, 1987; Zoback et al., 1987; Bunds, 2001], with strong faults distributing strain to far-field thrusts and weak fault zones experiencing near-field uplift and strike-slip faulting in the borderlands [e.g., Cowgill et al., $2004 a, 2004 b]$. The presence of rugged terrain at fault intersections along strike-slip fault zones suggests that secondary structures may play a dominant role on near-field deformation and exhumation, as shown by heterogeneous deformation at restraining bends considered to be mechanically stable [e.g., Yule and Sieh, 2003; Dair and Cooke, 2009]. The distribution of near-field deformation may also be related to across-strike variations in lithospheric strength [Griscom and Jachens, 1990; Magistrale and Sanders, 1996; Wakabayashi et al., 2004; Molnar and Dayem, 2010], with crustal shortening focused where strong basement is juxtaposed against weak crust. Because each of these factors may influence deformation along strike-slip faults, case studies are needed that best elucidate the primary controls on transpressive deformation.

[4] The San Emigdio Mountains are located along the western "Big Bend" of the San Andreas fault, a $300 \mathrm{~km}$ restraining bend with high obliquity $\left(>20^{\circ}\right)$ along the Pacific-North America plate boundary [Hill and Dibblee, 1953]. The range is considered to be topographically continuous with the rugged Transverse Ranges to the east (San Gabriel/San Bernardino Mountains), and exhibits a similar progressive increase in elevation from the mountain front in the southern San Joaquin Valley to the modern trace of the San Andreas fault (Figures 1a and 1b). Although high elevations along the trace of the San Andreas fault imply near-field deformation consistent with a "weak fault" [Cowgill et al., 2004a, 2004b], active crustal shortening at the range front along both blind and emergent thrust faults (Figures 1b and 2) [Keller et al., 1998] is consistent with the development of a far-field thrust system associated with a "strong" San Andreas fault [Cowgill et al., 2004a]. In addition to displaying behavior consistent with expectations for both "weak" and "strong" faults, the San Emigdio Mountains are also subject to structural complexities and rheologic heterogeneities. The intersection of secondary structures, including the Garlock and Lockwood Valley strike-slip faults, with the San Andreas fault may play a role in localizing crustal shortening, thus obscuring the role of the San Andreas fault in controlling near-field mountain building [e.g., Buscher and Spotila, 2007]. Further, the crystalline basement of the San Emigdio Mountains primarily consists of gneiss, granitoids, and schists emplaced at variable times and crustal depths [Dibblee, 1973; Ross, 1989; Pickett and Saleeby, 1994; Chapman et al., 2010], possibly generating zones of weakness that could alter block uplift paths and bulk lithospheric strength. The deformation observed in the San Emigdio Mountains is likely controlled by all of the above factors, and constraining the spatial and temporal variations in crustal shortening is a necessary step toward elucidating the relative magnitude of each. Such an understanding is key 

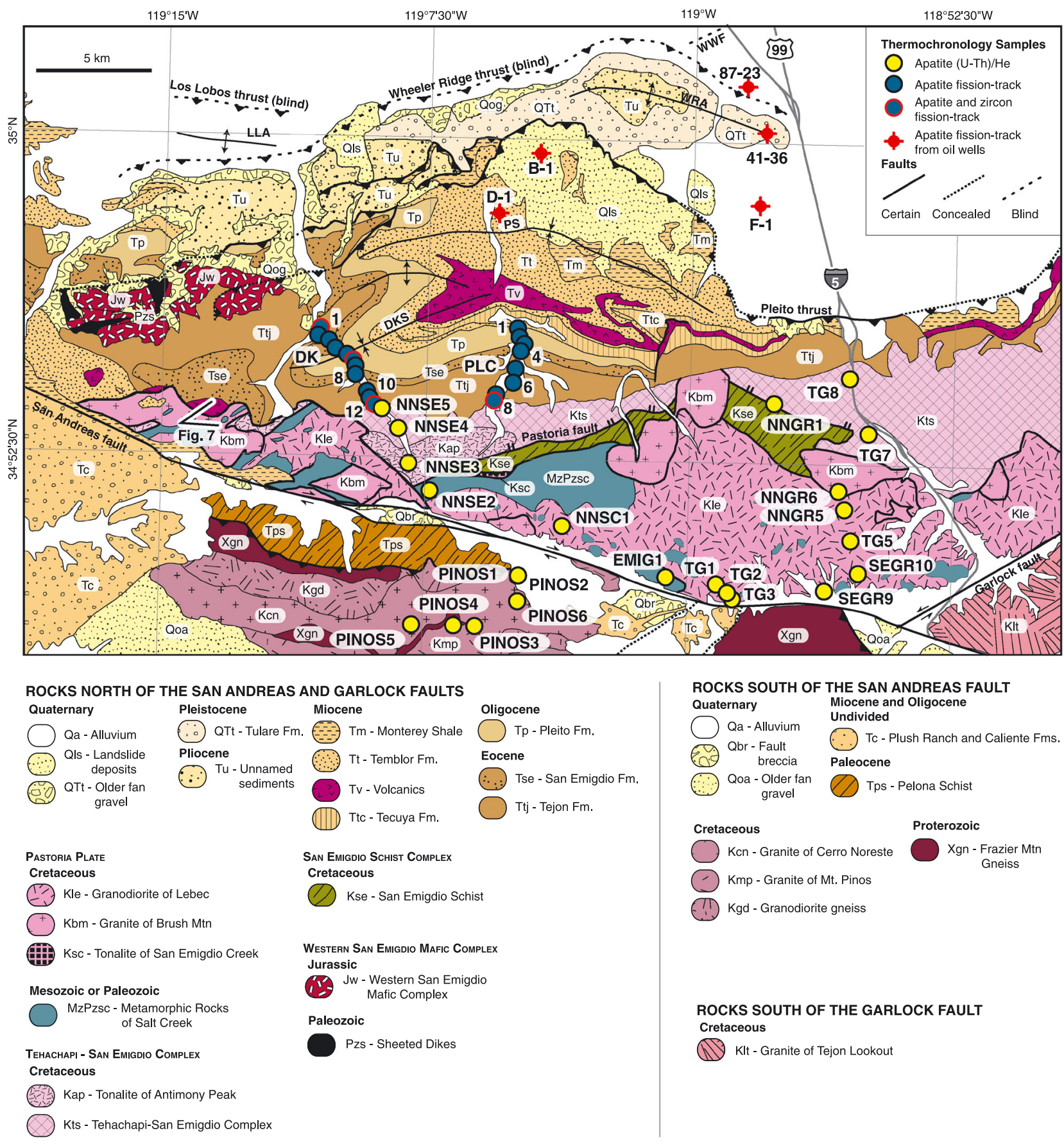

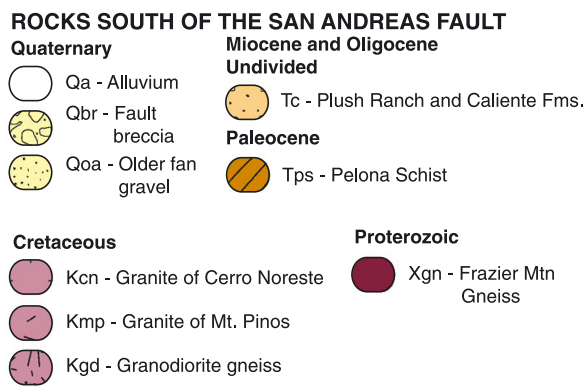

ROCKS SOUTH OF THE GARLOCK FAULT Cretaceous

(11) Klt - Granite of Tejon Lookout

Figure 2. Geologic map of the San Emigdio Mountains, California, and adjacent regions, showing locations of important tectonic features, and surface and subsurface low-temperature thermochronometry sample locations. Abbreviations on the map for geologic structures are DKS, Devil's Kitchen syncline; LLA, Los Lobos anticline; PS, Pleito syncline; WRA, and Wheeler Ridge anticline. (U-Th)/He samples are labeled with complete sample names. Surface fission track samples are shown by sample group, DK and PLC, and were collected sequentially from north to south in 1989. Sample numbers are a composite of sample group, number, and year collected, e.g., DK-1-89 (Table 1). Subsurface samples are from wells indicated on the Figure (Tables 2 and 3). The photograph in Figure 7 was taken from the viewpoint marked by the large "V" symbol in the west-central portion of the figure. Geology modified from [Dibblee, 1973; Ross, 1989; Chapman and Saleeby, 2012].

to resolving deformation in transpressional settings and the structural geometries associated with fault bends along the San Andreas and other transpressional plate boundary faults [Anderson, 1990; Fitzgerald et al., 1993; Tippett and Kamp,
1993; Foster et al., 1994; Yule and Sieh, 2003; Cunningham, 2007; Dair and Cooke, 2009; Benowitz et al., 2011, 2013]. To quantify the tectonic deformation of the San Emigdio Mountains and help distinguish the long-term drivers of 
landscape development from the gross distribution of structures seen at the surface, we have analyzed bedrock and detrital samples using low-temperature thermochronometry.

\section{Geologic Setting}

[5] The San Emigdio Mountains are an east-west trending mountain range that lies at the southern end of the San Joaquin Valley (Figure 1a). Although physiographically included as part of the Transverse Ranges of southern California due to its orientation, geologically, the San Emigdio Mountains are an extension of the southern Sierra Nevada [e.g., Ross, 1989]. The range lies at the western end of the Big Bend of the San Andreas fault (SAF), and is bounded on nearly all sides by active faults, including the Carrizo segment of the SAF to the west and south [ 34 mm/yr, Sieh and Jahns, 1984; Salyards, 1989]; the Garlock fault to the southeast $[\sim 7.6 \mathrm{~mm} / \mathrm{yr}, M c$ Gill et al., 2009], and a series of both emergent and blind faults to the north that dip southward underneath the range [Dibblee, 1973; Davis, 1983; Keller et al., 1998] (Figure 2).

[6] Evidence of active crustal shortening in the range is provided by historic seismicity, including the $1952 M_{w} 7.3$ Kern County earthquake (Figure 1b) [Gutenberg, 1955; Richter, 1955; Bawden et al., 1997], modern geodetic measurements of strain across the region [Bawden et al., 1997], and active folding of Quaternary sediments along the northern range front above blind thrust faults (Figure 2) [Medwedeff, 1988; Keller et al., 1998, 2000]. Paleoseismic studies and surface ruptures associated with the $1857 M 7.9$ Fort Tejon earthquake record dextral strike-slip faulting along the San Andreas fault to the south of the range [Sieh, 1978; Lindvall et al., 2002].

[7] South of the San Emigdio Mountains, the San Andreas fault traverses a series of valleys with mean valley floor elevations near $1500 \mathrm{~m}$. From these valleys, the peaks of the San Emigdio Mountains rise sharply to $\sim 2000 \mathrm{~m}$. The highest portion of the range is underlain by plutonic and metamorphic rocks of Cretaceous age (Figure 2). These rocks represent two intrusive suites of differing ages and origin, separated by the Pastoria fault (Figure 2). To the north and east, gneisses and mafic intrusive rocks of the TehachapiSan Emigdio complex represent deep levels of the Sierra Nevada batholith [Ross, 1989; Pickett and Saleeby, 1994]. Intrusion and peak metamorphism occurred in the early Cretaceous, and the complex was subsequently rapidly unroofed in the Late Cretaceous [Saleeby et al., 1987; Saleeby et al., 2007]. Granitic and granodioritic rocks to the south and east of the Pastoria fault are Late Cretaceous in age (Figure 2 and Table 1) and represent significantly higher batholithic levels of the Sierran arc [Chapman et al., 2011; Chapman et al., 2012].

[8] Unconformably overlying the basement is a sequence of marine and nonmarine sedimentary rocks ranging in age from Eocene to Quaternary [McGill, 1951; Dibblee, 1973; Nilsen et al., 1973; DeCelles, 1988; Rhoades and DeCelles, 1995; Critelli and Nilsen, 2000; Keller et al., 2000]. These strata have been folded and faulted over the southern edge of the San Joaquin Valley, such that the oldest strata are exposed just below the highest peaks of the range, and the youngest rocks are exposed $\sim 2000 \mathrm{~m}$ lower, on the edge of the valley floor (Figure 2) [Dibblee, 1961; Davis, 1983; Medwedeff, 1988; Namson and Davis, 1988b; Keller et al., 1998]. A detailed record of changes in depositional environment, sea level, and tectonic boundary conditions through late Cenozoic time is preserved in this stratigraphic sequence [e.g., DeCelles, 1988; Goodman and Malin, 1992]. Major transitions in tectonic boundary conditions interpreted from this record are a change from Oligocene-early Miocene regional extension to middle Miocene strike-slip dominated deformation, followed by a later transition to compressional dominated deformation in Pliocene time [Goodman and Malin, 1992].

[9] The San Andreas fault juxtaposes the Frazier MountainMount Pinos block against the southern edge of the San Emigdio Mountains (Figure 2). The Frazier MountainMount Pinos block is comprised primarily of gneisses of Proterozoic age, intruded by Cretaceous granitoids of the Peninsular Ranges batholith [Carman, 1964; Ross, 1972; Kellogg et al., 2008]. Overlying the basement rock are Oligocene-Miocene strata of the Plush Ranch Formation [Carman, 1964], which were deposited during an episode of extension in the California borderlands in early Miocene time [Bohannon, 1976; Cole and Stanley, 1995]. The Pliocene Quatal Formation unconformably overlies both basement and pre-Pliocene Cenozoic strata, and preserves evidence of modest contractional shortening over the last $5 \mathrm{Ma}$ [Kellogg and Minor, 2005].

[10] Correlation of igneous basement, and Oligo-Miocene sedimentary and volcanic strata suggest that the Frazier Mountain-Mount Pinos block shares an affinity with the Orocopia and Chocolate mountains of southeastern California [Crowell and Walker, 1962; Powell, 1981; Ballance et al., 1983; Frizzell and Weigand, 1993; Matti and Morton, 1993], although direct correspondence between specific igneous and sedimentary units remains equivocal [Ross, 1972; Law et al., 2001].

\section{Low-temperature Thermochronometry Data Sets}

[11] We present 16 new apatite (U-Th)/He (AHe) ages from the San Emigdio Mountains (Figures 2 and 3 and Table 1). We combine these data with seven published AHe ages from the San Emigdio Mountains and Mount Pinos [Spotila et al., 2007b] (Figures 2 and 3 and Table 1) and previously unpublished fission track data produced under contract to ARCO Western Energy [White et al., 1991]. The fission track data set includes 19 apatite (AFT) and 4 zircon (ZFT) ages from sedimentary and igneous rocks in the San Emigdio Mountains, and 13 apatite and 6 zircon fission track ages from subsurface samples collected from wells in the southern San Joaquin basin [White et al., 1991] (Figures 2 and 3; Tables 2 and 3; Appendix A. Track length data are available in Table A2. Many apatite grains were also analyzed by electron microprobe to determine the affect of apatite chemistry on annealing [Ketcham, 2005] (Table S1)). AHe and AFT ages were used to constrain the timing and rate of exhumation along the western end of the Big Bend of the San Andreas fault. The suite of thermochronometers used in this study have closure temperatures of $\sim 70^{\circ} \mathrm{C}(\mathrm{AHe}), \sim 110^{\circ}$ $\mathrm{C}$ (AFT), and $\sim 250^{\circ} \mathrm{C}$ (ZFT), dependent on cooling rate, grain size, and radiation damage [Gleadow and Duddy, 1991; Tagami et al., 1996; Farley, 2000, 2002; Shuster et al., 2006; Flowers et al., 2007]. The temperature range covered by these thermochronometers is broad, and is sensitive to the 
Table 1. (U-Th)/He and Fission Track Analyses

\begin{tabular}{|c|c|c|c|c|c|c|}
\hline & Longitude & Latitude & Elevation & Mean Age & Lithologic Unit $^{\mathrm{a}}$ & Lithologic Unit Age \\
\hline Sample & $\left({ }^{\circ} \mathrm{W}\right)$ & $\left({ }^{\circ} \mathrm{N}\right)$ & $(\mathrm{m})$ & (Ma) & & (Ma) \\
\hline \multicolumn{7}{|c|}{ Apatite $(U-T h) / H e$ Ages } \\
\hline EMIG-1 & 119.00860 & 34.82730 & 1646 & $4.2 \pm 2.4$ & Quartzofeldspathic gneiss of Pastoria Creek & 112 \\
\hline TG-1 & 118.98615 & 34.82765 & 1933 & $7.5 \pm 1.3$ & Granodiorite of Lebec (landslide?) & $88-92$ \\
\hline TG-2 & 118.98072 & 34.82440 & 1790 & $8.7 \pm 1.5$ & Metasediments of Salt Creek (landslide?) & $\mathrm{Pz}$ \\
\hline TG-3 & 118.97838 & 34.82193 & 1628 & $5.7 \pm 1.0$ & Metasediments of Salt Creek & $\mathrm{Pz}$ \\
\hline TG-5 & 118.92276 & 34.84550 & 1428 & $11.7 \pm 2.0$ & Granodiorite of Lebec & $88-92$ \\
\hline TG-7 & 118.91516 & 34.88740 & 974 & $38.5 \pm 6.6$ & Quartzofeldspathic gneiss of Pastoria Creek & 112 \\
\hline TG-8 & 118.92447 & 34.90891 & 695 & $59.0 \pm 10.1$ & Quartzofeldspathic gneiss of Pastoria Creek & 112 \\
\hline NNGR-1 & 118.96017 & 34.89861 & 1241 & $55.6 \pm 9.3$ & Quartzofeldspathic gneiss of Pastoria Creek & 112 \\
\hline NNGR-5 & 118.92595 & 34.85773 & 1595 & $12.9 \pm 2.2$ & Granodiorite of Lebec & $88-92$ \\
\hline NNGR-6 & 118.92897 & 34.86483 & 1522 & $12.6 \pm 2.1$ & Granite of Brush Mountain & 105 \\
\hline NNSC-1 & 119.05969 & 34.84976 & 1873 & $5.1 \pm 0.9$ & Granodiorite of Lebec & $88-92$ \\
\hline NNSE-2 & 119.12646 & 34.86158 & 1402 & $4.4 \pm 0.7$ & Metasediments of Salt Creek & $\mathrm{Pz}-\mathrm{Mz}$ \\
\hline NNSE-3 & 119.13305 & 34.87295 & 1287 & $5.2 \pm 0.9$ & Quartz diorite-tonalite of Antimony Peak & 135 \\
\hline NNSE-4 & 119.13811 & 34.88657 & 1179 & $4.4 \pm 0.7$ & Quartzofeldspathic gneiss of Pastoria Creek & 112 \\
\hline NNSE-5 & 119.14586 & 34.89428 & 1100 & $6.7 \pm 1.1$ & Quartzofeldspathic gneiss of Pastoria Creek & 112 \\
\hline SEGR-9 & 118.93487 & 34.82565 & 1420 & $7.9 \pm 1.3$ & Granodiorite of Lebec & $88-92$ \\
\hline SEGR-10 & 118.91890 & 34.83282 & 1651 & $9.6 \pm 1.5$ & Granodiorite of Lebec & $88-92$ \\
\hline PINOS-1 & 119.07547 & 34.83247 & 1903 & $37.7 \pm 5.7$ & Granite of Cerro Noreste (landslide?) & 67.2 \\
\hline PINOS-2 & 119.07652 & 34.81684 & 2049 & $23.2 \pm 3.5$ & Granite of Cerro Noreste & 67.2 \\
\hline PINOS-3 & 119.10011 & 34.81163 & 2244 & $22.9 \pm 3.4$ & Granite of Cerro Noreste & 67.2 \\
\hline PINOS-4 & 119.11190 & 34.80838 & 2402 & $27.0 \pm 4.1$ & Granite of Mount Pinos & 76.1 \\
\hline PINOS-5 & 119.12631 & 34.81228 & 2537 & $21.9 \pm 3.3$ & Granite of Cerro Noreste & 67.2 \\
\hline PINOS-6 & 119.07835 & 34.81814 & 2049 & $21.7 \pm 3.3$ & Granite of Cerro Noreste & 67.2 \\
\hline \multicolumn{7}{|c|}{ Apatite Fission Track Ages } \\
\hline PLC-1-89 & 119.08271 & 34.92655 & 903 & $44.3 \pm 3.4$ & Pleito Formation & $34-23$ \\
\hline PLC-2-89 & 119.08182 & 34.92286 & 912 & $41.5 \pm 4.1$ & Pleito Formation & $34-23$ \\
\hline PLC-3-89 & 119.07912 & 34.92050 & 976 & $19.9 \pm 3.2$ & Pleito Formation & $34-23$ \\
\hline PLC-4-89 & 119.08067 & 34.91756 & 953 & $43.9 \pm 4.0$ & San Emigdio Formation & $39-34$ \\
\hline PLC-5-89 & 119.08309 & 34.91070 & 1021 & $48.5 \pm 4.7$ & Tejon Formation & $52.5-39$ \\
\hline PLC-6-89 & 119.08410 & 34.90546 & 1110 & $36.9 \pm 3.1$ & Tejon Formation & $52.5-39$ \\
\hline PLC-7-89 & 119.09191 & 34.89993 & 1129 & $13.5 \pm 1.7$ & Tejon Formation & $52.5-39$ \\
\hline PLC-8-89 & 119.09207 & 34.89949 & 1134 & $10.8 \pm 1.5$ & Quartzofeldspathic gneiss of Pastoria Creek & 112 \\
\hline DK-1-89 & 119.17594 & 34.92516 & 846 & $19.4 \pm 2.4$ & Tejon Formation & $52.5-39$ \\
\hline DK-2-89 & 119.17681 & 34.92272 & 847 & $26.7 \pm 3.4$ & Tejon Formation & $52.5-39$ \\
\hline DK-3-89 & 119.17160 & 34.92013 & 911 & $44.6 \pm 4.3$ & Tejon Formation & $52.5-39$ \\
\hline DK-4-89 & 119.16851 & 34.91742 & 912 & $17.9 \pm 2.9$ & San Emigdio Formation & $39-34$ \\
\hline DK-5-89 & 119.16295 & 34.91490 & 964 & $24.1 \pm 2.4$ & Pleito Formation & $34-23$ \\
\hline DK-6-89 & 119.15936 & 34.91212 & 976 & $18.7 \pm 2.2$ & Pleito Formation & $34-23$ \\
\hline DK-7-89 & 119.15877 & 34.91052 & 984 & $27.4 \pm 3.6$ & Pleito Formation & $34-23$ \\
\hline DK-8-89 & 119.15913 & 34.90696 & 1019 & $12.7 \pm 3.0$ & San Emigdio Formation & $39-34$ \\
\hline DK-10-89 & 119.15290 & 34.90091 & 1050 & $13.9 \pm 2.1$ & Tejon Formation & $52.5-39$ \\
\hline DK-11-89 & 119.15103 & 34.89798 & 1069 & $17.0 \pm 2.8$ & Tejon Formation & $52.5-39$ \\
\hline DK-12-89 & 119.15064 & 34.89730 & 1073 & $16.5 \pm 3.5$ & Quartzofeldspathic gneiss of Pastoria Creek & 112 \\
\hline \multicolumn{7}{|c|}{ Zircon Fission Track Ages } \\
\hline PLC-8-89 & 119.09207 & 34.89949 & 1134 & $62.9 \pm 3.9$ & Quartzofeldspathic gneiss of Pastoria Creek & 112 \\
\hline DK-1-89 & 119.17594 & 34.92516 & 846 & $79.7 \pm 6.0$ & Tejon Formation & $52.5-39$ \\
\hline DK-6-89 & 119.15936 & 34.91212 & 976 & $87.7 \pm 10$ & Pleito Formation & $34-23$ \\
\hline DK-12-89 & 119.15064 & 34.89730 & 1073 & $64.7 \pm 6.8$ & Quartzofeldspathic gneiss of Pastoria Creek & 112 \\
\hline
\end{tabular}

a Lithologic unit designations from Ross [1989], Dibblee [1973], Saleeby et al. [2007], and Chapman and Saleeby [2012], with the exception of the PINOS series of samples, which are from Kellogg and Miggins [2002] and Kellogg [2003].

${ }^{b}$ Lithologic unit ages are crystallization or peak metamorphic ages for plutonic and metamorphic rocks [James, 1986; Saleeby et al., 1987; James and Mattinson, 1988; Pickett and Saleeby, 1994; Kellogg, 1999; Kellogg and Miggins, 2002; Saleeby et al., 2007; Chapman et al., 2012], with the exception of the Metasediments of Salt Creek, which are constrained only to be of Paleozoic age [Chapman and Saleeby, 2012; Chapman et al., 2012]. Ages of sedimentary rocks are given as the ages of the upper and lower bounding stratigraphic contacts [Nilsen et al., 1973].

thermal history of erosional exhumation in the upper several kilometers of the Earth's crust.

\section{1. (U-Th)/He Apatite Ages}

[12] Apatite for (U-Th)/He thermochronometry was separated from samples collected both north of the San Andreas fault, in the San Emigdio Mountains, and south of the San Andreas fault, from Mount Pinos. Both igneous and metamorphic rocks were sampled in the San Emigdio Mountains (Figure 2 and Table 1), with all rocks having Cretaceous crystallization or peak metamorphic ages (Figure 2 and Table 1).
On the south side of the San Andreas fault, samples were collected from granitoids with Late Cretaceous crystallization ages (Figure 2 and Table 1).

[13] Apatite (U-Th)/He ages from samples in the San Emigdio Mountains range from 59-4.2 Ma (Table 1), while those from Mount Pinos range from 38-22 Ma (Table 1). On both sides of the fault, the AHe ages are significantly younger than the crystallization or peak metamorphic ages of the rocks from which they were collected, signifying that these ages record a postintrusion or postmetamorphic cooling event. AHe ages from samples south of the San Andreas fault 


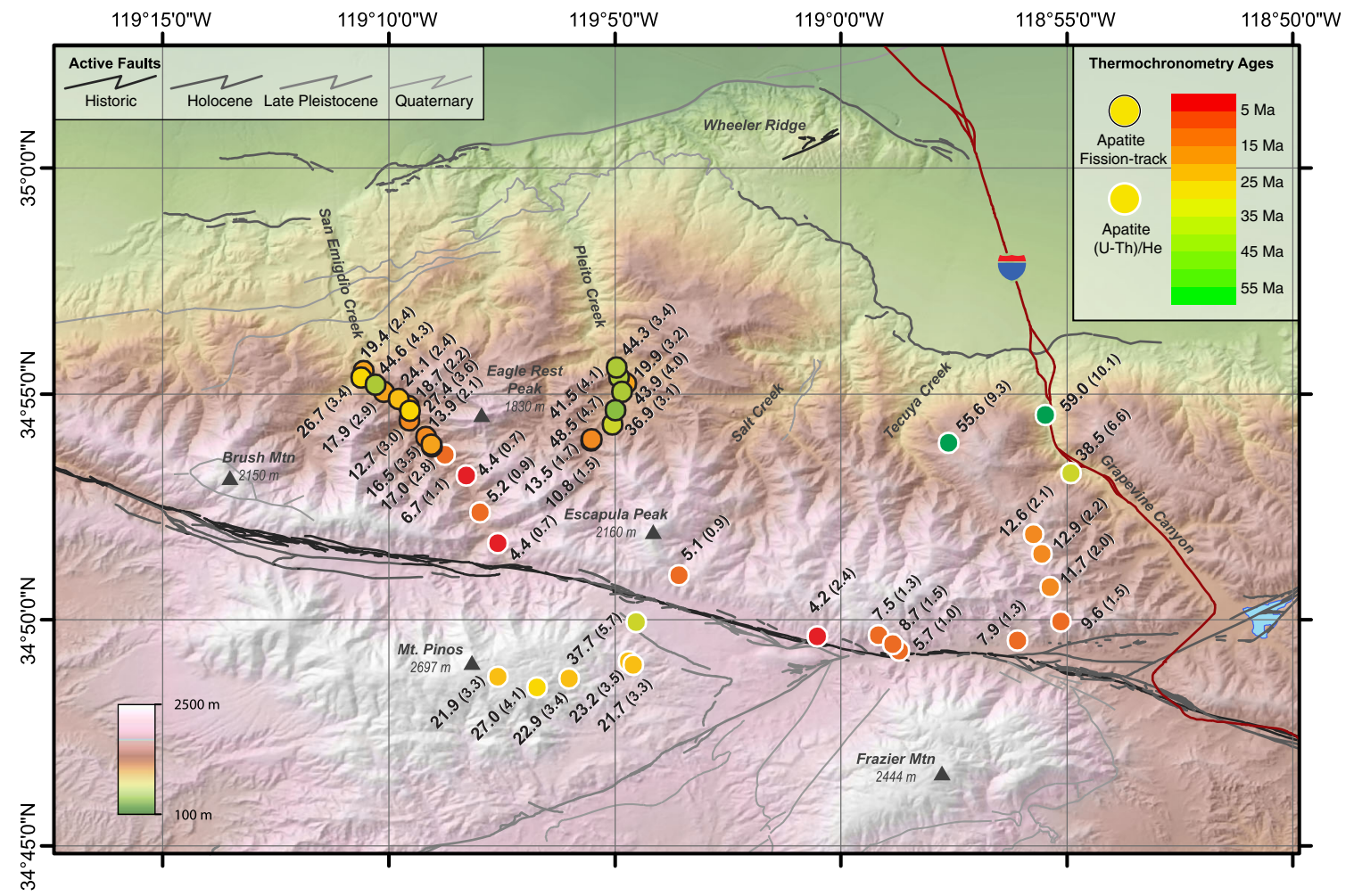

Figure 3. Shaded relief map of the San Emigdio and Mount Pinos regions showing the locations and ages of apatite and zircon fission track and apatite (U-Th)/He sample locations relative to the San Andreas fault and other geographic localities of interest noted in the text. Ages in Ma with errors in parentheses.

are largely age-invariant with respect to elevation. Those from the north also demonstrate little or no age-elevation dependence, but the ages do young from north to south toward the San Andreas fault (Figures 2 and 3).

\subsection{Apatite and Zircon Fission Track Ages}

[14] Samples for apatite and zircon fission track dating were collected from the San Emigdio Mountains and from oil field wells in the southern end of the San Joaquin Valley (Figure 2 and Tables 1 and 3). With the exception of two samples that were collected from igneous and metamorphic basement rocks (DK-12-89 and PLC-8-89), all of the samples were collected from Paleogene or Neogene marine and nonmarine sandstones (Figure 2 and Table 1). The AFT dates were collected as part of a study for ARCO Western Energy [White et al., 1991; White, 1992], and the separates are no longer available for further analysis. AFT ages for the surface samples range from 49-11 Ma, and ZFT ages from a subset of these samples range from 88-63 Ma (Table 1). Fission track ages from the subsurface samples range from $65-10 \mathrm{Ma}$ for apatite (Figure 3) and from 158-78 Ma for zircon. As with the AHe ages from north of the SAF, the surface AFT ages show an increase in age with distance from the SAF (Figures 2 and 3 and Table 1).

\subsubsection{Inherited Versus Reset Fission Track Ages}

[15] The apatite and zircon grains separated from Paleogene and Neogene sandstones in the San Emigdio Mountains are detrital, thus, interpreting the fission track ages requires a determination of whether these ages are inherited or reset. Reset ages result from heating and annealing of the fission tracks after deposition of the sandstones, and are related to the exhumation and cooling history of the sandstones themselves. Inherited fission track ages would instead record an earlier history of the unroofing and erosion of the source rocks of the detrital apatite and zircon. One means of making this distinction is to compare the fission track ages of the samples with the depositional age of the sandstones from which they were collected. If the fission track age is younger than the depositional age, then the fission track age is likely affected by burial and subsequent exhumation of the sandstones. If the fission track age is older than the depositional age of the unit from which it was collected, then this age is recording

Table 2. Locations of Sampled ARCO Western Energy Wells

\begin{tabular}{|c|c|c|c|c|c|c|c|}
\hline Lease & Well No. & Longitude $\left({ }^{\circ} \mathrm{W}\right)$ & Latitude $\left({ }^{\circ} \mathrm{N}\right)$ & Section & Township ${ }^{\mathrm{a}}$ & Range $^{a}$ & Total Depth (m) \\
\hline KCL F & $41-36$ & 118.96660 & 35.00455 & 36 & $11 \mathrm{~N}$ & $20 \mathrm{~W}$ & 3693 \\
\hline ROC-KCL G & $87-23$ & 118.97593 & 35.02258 & 23 & $11 \mathrm{~N}$ & $20 \mathrm{~W}$ & 3715 \\
\hline San Emigdio B & 1 & 119.07338 & 34.99511 & 36 & $11 \mathrm{~N}$ & $21 \mathrm{~W}$ & 4340 \\
\hline San Emgidio D & 1 & 119.09241 & 34.97153 & 11 & $10 \mathrm{~N}$ & $21 \mathrm{~W}$ & 3751 \\
\hline San Emigdio F & 1 & 118.96911 & 34.97625 & 1 & $10 \mathrm{~N}$ & $20 \mathrm{~W}$ & 4501 \\
\hline
\end{tabular}

${ }^{\mathrm{a} S}$ San Bernardino Baseline and Meridian. 
Table 3. Apatite and Zircon Fission Track Ages for Well Samples

\begin{tabular}{lcccc}
\hline Sample & $\begin{array}{c}\text { Depth } \\
(\mathrm{m})\end{array}$ & $\begin{array}{c}\text { AFT Age } \\
(\mathrm{Ma})\end{array}$ & $\begin{array}{c}\text { ZFT Age } \\
(\mathrm{Ma})\end{array}$ & Stratigraphic Age \\
\hline \multicolumn{5}{c}{ San Emigdio B1 } \\
B1 9455-61 & 2882 & $45.1 \pm 5.9$ & $78.4 \pm 20$ & L. Zemorrian (32 Ma) \\
B1 12753-78 & 3887 & $44.0 \pm 4.5$ & $157.8 \pm 29$ & Eocene (43 Ma) \\
B1 14040 & 4279 & $35.7 \pm 14.3$ & N.D. & Granitic basement \\
\multicolumn{5}{c}{ San Emigdio D1 } \\
D1 6433-48 & 1961 & $38.0 \pm 3.7$ & $118.6 \pm 12$ & Saucesian (?) (23 Ma) \\
D1 10314-34 & 3144 & $54.9 \pm 6.8$ & N.D. & Refugian (?) (36 Ma) \\
D1 11118-75 & 3389 & $48.1 \pm 4.7$ & $115.1 \pm 23$ & Eocene (41 Ma) \\
\multicolumn{5}{c}{ San Emigdio F1 } \\
F1 9262-76 & 2823 & $58.8 \pm 5.7$ & N.D. & Saucesian (23 Ma) \\
F1 11142-62 & 3396 & $31.1 \pm 3.8$ & $85.4 \pm 5$ & U. Zemorrian (28 Ma) \\
F1 12446-66 & 3794 & $17.1 \pm 12.4$ & N.D. & L. Zemorrian (29 Ma) \\
F1 14708-31 & 4483 & $10.0 \pm 2.3$ & N.D. & Eocene (44 Ma) \\
\multicolumn{5}{c}{ KCL F41-36 } \\
F41-36 12080 & 3682 & $11.0 \pm 2.6$ & N.D. & Eocene (40 Ma) \\
\multicolumn{5}{c}{ ROC-KCL G87-23 } \\
KCL 87-23 8532 & 2601 & $62.6 \pm 5.8$ & $82.7 \pm 13$ & U. Zemorrian (25 Ma) \\
KCL 87-23 9365-94 2854 & $65.2 \pm 6.6$ & N.D. & U. Zemorrian (29 Ma) \\
\hline \multicolumn{5}{c}{}
\end{tabular}

information about an earlier exhumational event that affected the source rock. In addition, tracks that reside in the partial annealing zone for extended periods of time will have short mean track lengths of $10-13 \mu \mathrm{m}$.

[16] Absolute depositional ages for the sandstones in the San Emigdio Mountains can be derived from the benthic foraminiferal zones of these strata, which are well known in California [Kleinpell, 1938; Mallory, 1959; Almgren et al., 1988]. These zones have been tied to an absolute timescale through magnetostratigraphy (Figure 4) [e.g., Prothero, 2001]. The majority of AFT ages for samples included in this study are younger than the depositional age of the rock from which they were collected, but this is not universally the case (Figure 4). Five of the samples yield mean apatite fission track ages that are older than their associated depositional age, and the spread of grain ages from all of the apatite samples includes ages that are both older and younger than the depositional age of the sample. The scatter in grain ages is caused largely by variations in apatite chemistry (Table $\mathrm{S} 1)$. In particular, high $\mathrm{Cl}$ content can retard annealing. The mean track lengths of the surface samples are generally in the $11.8-12.9 \mu \mathrm{m}$ range, consistent with burial and residence at temperatures of $60^{\circ} \mathrm{C}-80^{\circ} \mathrm{C}$ during Eocene-Miocene time (Table A2). Thus, the apatite fission track ages appear to record the postdepositional thermal history of the sandstones.

[17] Zircon fission track ages from both surface and subsurface samples are uniformly older than the strata from which they were collected (Figure 4), and presumably record the thermal history of the source terrane from which they were derived [White et al., 1991]. The fission track ages present in the zircon population suggest that they record either crystallization ages of Late Cretaceous granitoids south of the Pastoria fault (Figure 2) [Ross, 1989], or rapid

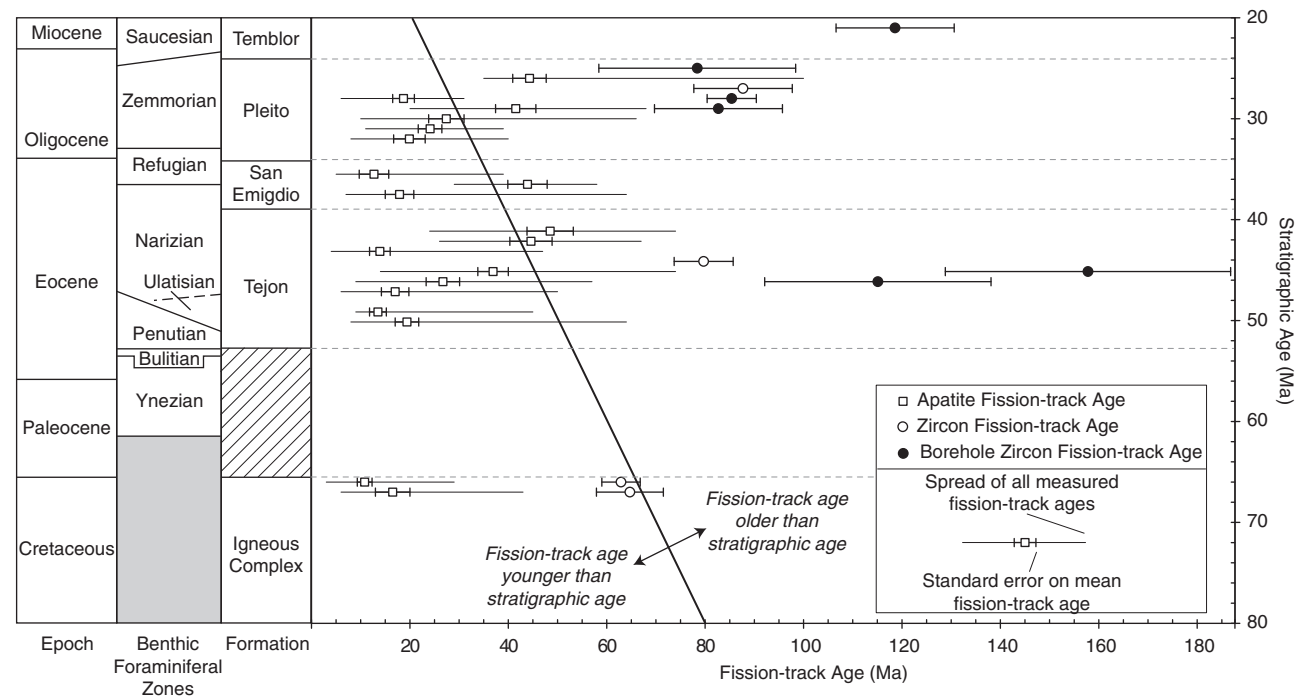

Figure 4. Comparison of apatite (AFT) and zircon (ZFT) fission track ages from surface and subsurface samples with stratigraphic age. Samples that plot to the lower left of the diagonal line in the right panel of the figure have younger AFT or ZFT ages than stratigraphic ages, and must have experienced partial annealing. Samples that plot to the upper right of the line have AFT or ZFT ages older than the stratigraphic age and likely have inherited ages. Stratigraphic age is plotted as a function of lithostratigraphic position for clarity (a sample collected from the base of the Tejon Fm. is plotted with an older stratigraphic age than a sample collected from the top of the Tejon Fm.); however, the error in stratigraphic age for all samples is considered to be the bounding lithologic contacts. The mean AFT age for the majority of samples is younger than the stratigraphic age, and all but one AFT sample yielded measured ages younger than the stratigraphic age, indicating that the AFT ages are a result of partial annealing. This interpretation is supported by both ZFT surface and subsurface samples, which yield exclusively Mesozoic ages. If the observed 40$50 \mathrm{Ma}$ AFT ages were derived from an Eocene source, Cenozoic ZFT ages would also be expected. Geologic time scale from Gradstein et al. [2004]. Benthic foraminiferal zones and time scale for California from Kleinpell [1938], Mallory [1959], Almgren et al. [1988] and Prothero [2001]. Lithostratigraphy for the San Emigdio Mountains from Nilsen [1973]. 


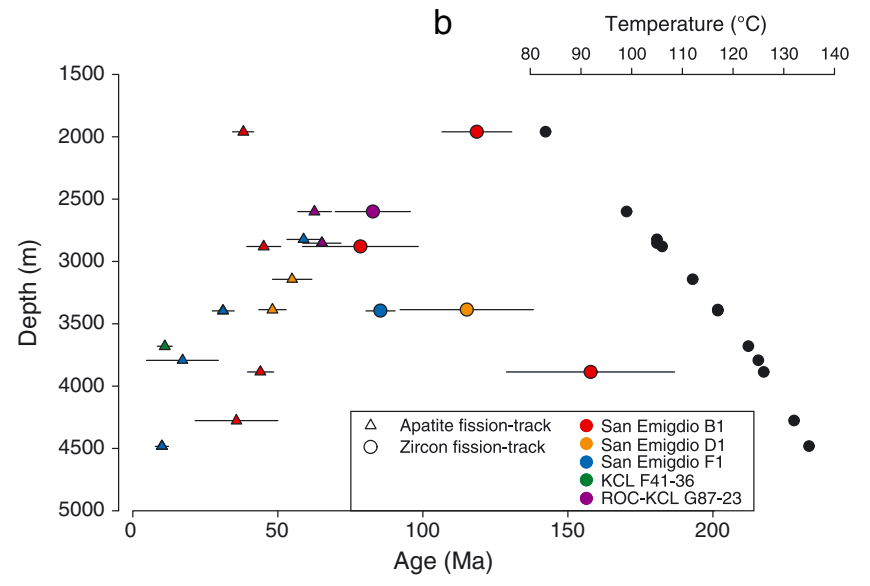

a

Figure 5. (a) Plot of apatite and zircon fission track ages with depth for subsurface sandstone samples recovered from boreholes in the southern San Joaquin Valley (Figure 2 and Tables 2 and 3). Zircon fission track ages are Mesozoic in age and are older at greater depths, perhaps reflecting a contribution of zircons from younger source terranes through time. Apatite fission track samples are generally Cenozoic in age and are younger with increased depth, suggesting that the deeper samples are undergoing partial annealing. (b) Plot of estimated temperature with depth in the wells. The closure temperature of fission tracks in apatite is estimated to be $100^{\circ} \pm 20^{\circ} \mathrm{C}$ [Wagner, 1968; Naeser and Faul, 1969], while that in zircons is estimated to be $\sim 250^{\circ} \mathrm{C}$ [Tagami et al., 1996]. Tracks in apatite grains below $\sim 1.5 \mathrm{~km}$ depth in these wells are currently annealing, while tracks in zircons are not, in agreement with the age-depth relationships plotted in (a).

exhumation of the Tehachapi and San Emigdio basement in Late Cretaceous time [Saleeby et al., 2007; Chapman et al., 2011, 2012], consistent with detrital zircon U-Pb geochronology that demonstrates a Sierran affinity source for the Tejon Formation in the San Emigdio Mountain [Lechler and Niemi, 2011].

[18] A comparison of AFT and ZFT ages with depth for the subsurface samples confirms that the AFT ages are likely partially to fully reset (Figure 5). Cretaceous ZFT ages show a systematic increase in age with depth, potentially recording sequential exhumation of the Tehachapi Mountains [White et al., 1991], while the AFT ages are Paleocene to Miocene in age and young with depth (Figure 5a). The track lengths are generally short $(10.1-13.3 \mu \mathrm{m})$. Mean $\mathrm{Cl}$ contents are $<0.4 \mathrm{wt} \%$, although one sample has a mean chlorine content of $0.6 \mathrm{wt} \%$. Temperature plotted as a function of downhole depth (Figure 5b), indicates that temperatures at or above the annealing temperature of fission tracks in apatite are reached in the lower portions of the wells.

[19] We conclude that the apatite fission track ages from all of the surface samples are the product of full or partial annealing due to postdepositional burial and that the resulting apatite fission track ages record the exhumation of the Paleogene section. The zircon fission track ages, on the other hand, appear to be entirely inherited, and reflect an earlier cooling event that affected the source rocks of the sandstones. The thermal histories of these zircons are not further considered in the discussion of the tectonic evolution of transpression along the San Andreas fault.

\section{Thermochronologic Data Interpretation}

[20] One of the most common methods used to evaluate the rate and timing of rock exhumation from low-temperature thermochronometry data is to plot thermochronologic ages versus sample elevation [e.g., Fitzgerald et al., 1986]. Such plots have as an inherent assumption that the modern elevation difference between samples is identical to the paleodepth differences between the samples, or to put it another way, that the samples were exhumed from beneath horizontal topography with no significant tilting or deformation of the exhumed crust [e.g., Stockli et al., 2000] or without significant deflection of isotherms [Stüwe et al., 1994]. Given the assumptions inherent in this analysis, the slope of a line through sample ages in elevation space represents an exhumation rate, and a break in slope a change in exhumation rate or fossil partial annealing zone (PAZ; AFT)) or partial retention zone (PRZ; (U-Th)/He) [Fitzgerald et al., 1986; Stockli et al., 2000]. Samples from north and south of the San Andreas will be interpreted in this context, and then modifications to this approach will be presented.

\subsection{Mount Pinos Apatite (U-Th)/He Data}

[21] Samples collected from the Mount Pinos region yield a steep, nearly elevation-invariant, slope in age-elevation space, indicating that these samples may record the rapid exhumation of an intact crustal section (Figure 6a). One exception is the topographically lowest sample, which is significantly older than topographically higher samples. This sample, however, may have been collected from a large landslide block [Kellogg, 2003]. Discarding this sample, the steep slope of the age-elevation relationship suggests rapid exhumation began by the early Miocene ( $22 \mathrm{Ma})$. The timing of such an exhumational event is speculative, as no clear break in slope is preserved, and no reliable geologic datum can be established to demonstrate that sample elevation is a reliable proxy for sample depth. However, geologic mapping suggests broad, open folding of Cenozoic strata across the adjacent Lockwood Valley [Kellogg and Minor, 2005], indicating that large scale tilting of the Mount Pinos block since early Miocene cooling is unlikely. Thus, we interpret the thermochronometry data as recording rapid crustal cooling in early Miocene time.

[22] Palinspastic restoration of the San Andreas fault system and cross fault correlation of both basement geology [Crowell and Walker, 1962; Powell, 1981; Matti and Morton, 1993] and late Oligocene to early Miocene sedimentary and volcanic strata [Ballance et al., 1983; Frizzell and Weigand, 1993] place the Mount Pinos and Frazier Mountain region in the vicinity of the Orocopia Mountains of southeastern California prior to the initiation of a transform plate boundary. Sedimentary strata of the Plush Ranch and Simmler formations in the Mount Pinos region [Bohannon, 1976; Cole and Stanley, 1995] and of the Diligencia Formation in the Orocopia Mountains [Law et al., 2001] preserve evidence of extensional tectonism and basin formation in early Miocene time, consistent with thermochronological data from the footwall of the Orocopia detachment fault [Jacobson et al., 2007]. Thus, rapid exhumation of the Mount Pinos region in early Miocene time is best explained 

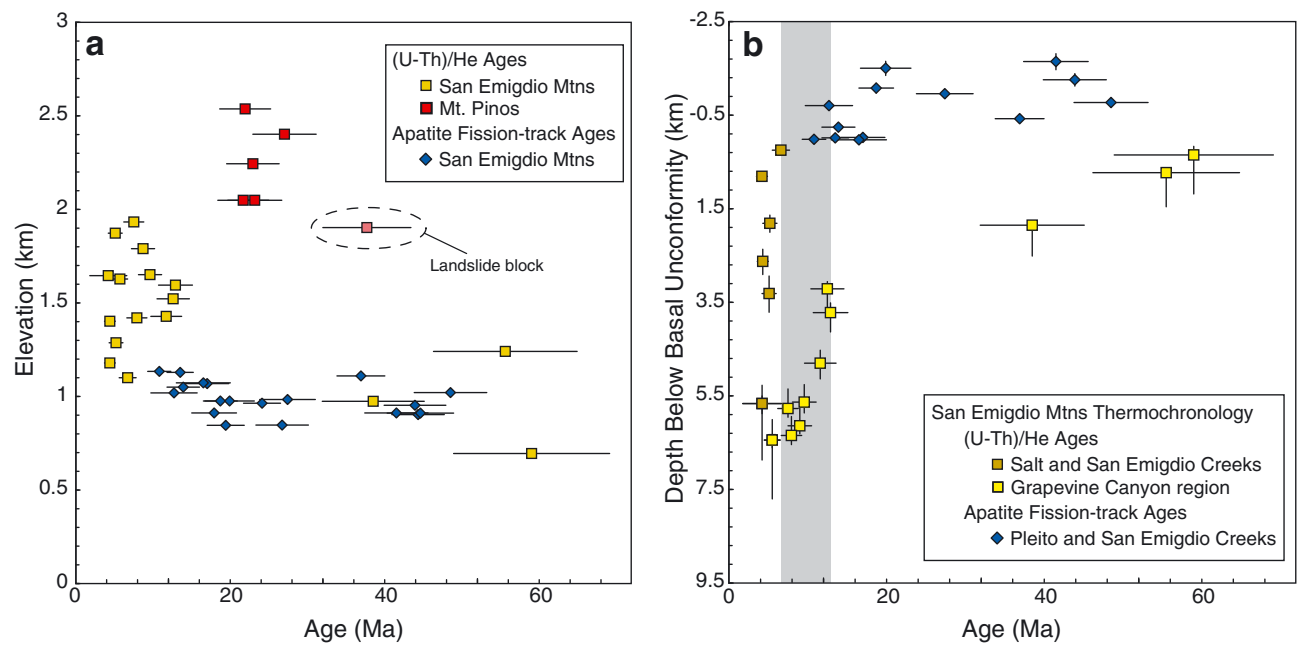

Figure 6. (a) Plot of apatite (U-Th)/He and fission track ages as a function of elevation for all surface samples collected. Samples from the San Emigdio Mountains, on the northern side of the San Andreas fault, display an inverse age-elevation relationship, apparently younging with increased elevation. Samples from Mount Pinos, on the southern side of the San Andreas fault are fairly age-invariant with elevation, with the exception of the lowest sample, which may have been collected from a large landslide block [Kellogg, 2003]. The age-elevation relationship from Mount Pinos is consistent with rapid cooling at $\sim 20-25 \mathrm{Ma}$, but such an interpretation of the data is neither unique nor definitive. The age-elevation relationship of samples from the San Emigdio Mountains plotted in present-day elevations is not interpretable in a tectonic context. (b) Apatite (U-Th)/He and fission track ages from the San Emigdio Mountains plotted against distance from the basal Tertiary unconformity (Figure 7). In this reference frame, thermochronologic data from two transects reveal a more typical age-depth relationship, recording slow cooling and the preservation of a partial He retention zone or partial fission track annealing zone, followed by increased rates of cooling and exhumation. The eastern transect, subparallel to and west of Grapevine Canyon and Interstate 5 (Figure 2) records exhumation of the basement rocks of the San Emigdio Mountains beginning at $\sim 12-14 \mathrm{Ma}$. The western transect, along San Emigdio Creek (Figure 2) records rapid exhumation beginning at $\sim 6 \mathrm{Ma}$. Note that the two linear trends of ages on the western transect are defined by two separate thermochronometric systems. Since apatite fission track ages record a higher closure temperature than apatite He ages, the intersection of the two age trends along the western transect likely represents the maximum age at which rapid exhumation began.

as the result of the expansion of early Miocene Basin and Range extension in southwestern Arizona and southeastern California westward toward the plate boundary during the transition from subduction to transform fault motion [Tennyson, 1989]. The low-temperature thermochronologic data from Mount Pinos do not preserve evidence for a younger phase of exhumation, consistent with the nature of diffuse contractional deformation observed in the region south of the SAF since late Miocene time [Kellogg and Minor, 2005].

\subsection{San Emigdio Mountains (U-Th)/He and Fission Track Data}

[23] In contrast with the samples from Mount Pinos, which yield a narrow range of ages, thermochronologic ages from the San Emigdio Mountains span from Cretaceous to Pliocene. The ages are progressively older with distance away from the San Andreas fault (Figure 3), but do not show a clearly interpretable relationship in age-elevation space (Figure 6a). Samples at the highest elevations record the youngest cooling ages, while samples lower in elevation record older ages. Such an inverse age-elevation relationship is difficult to interpret without invoking a complex and nonmonotonic crustal thermal regime [Behr and Platt, 2012], or decreasing relief through time [Benowitz et al., 2012]. Given the relatively well-constrained geologic history of the region, comprised of deposition and burial throughout much of the Cenozoic, followed by late (post middle Miocene) exhumation, neither of these solutions is particularly viable for this region. Alternatively, this age-elevation relationship can be explained if the crustal section from which the samples were collected was tilted or deformed during or after the cooling event recorded by the thermochronologic ages. One method to produce interpretable cooling age information from such a data set is to plot the cooling ages with respect to a common datum that may not be horizontal presently, but likely was nearly horizontal, prior to the onset of cooling and exhumation. Examples of such datums are low-relief geomorphic surfaces [e.g., Clark et al., 2005; Clark and Bilham, 2008] or stratigraphic unconformities [e.g., Reiners et al., 2000]. In the case of the samples from the San Emigdio Mountains, we propose the basal Tertiary unconformity as a predeformation datum against which to plot the thermochronologic data (Figure 7). This unconformity is developed on the igneous and metamorphic basement rocks of the southern Sierra Nevada (Figure 2) [Ross, 1989; Chapman and Saleeby, 2012], and is overlain by the Eocene Tejon Formation (Figure 2) [Nilsen et al., 1973]. The basal member of the Tejon Formation, the Uvas Conglomerate Member, contains clasts of the underlying 


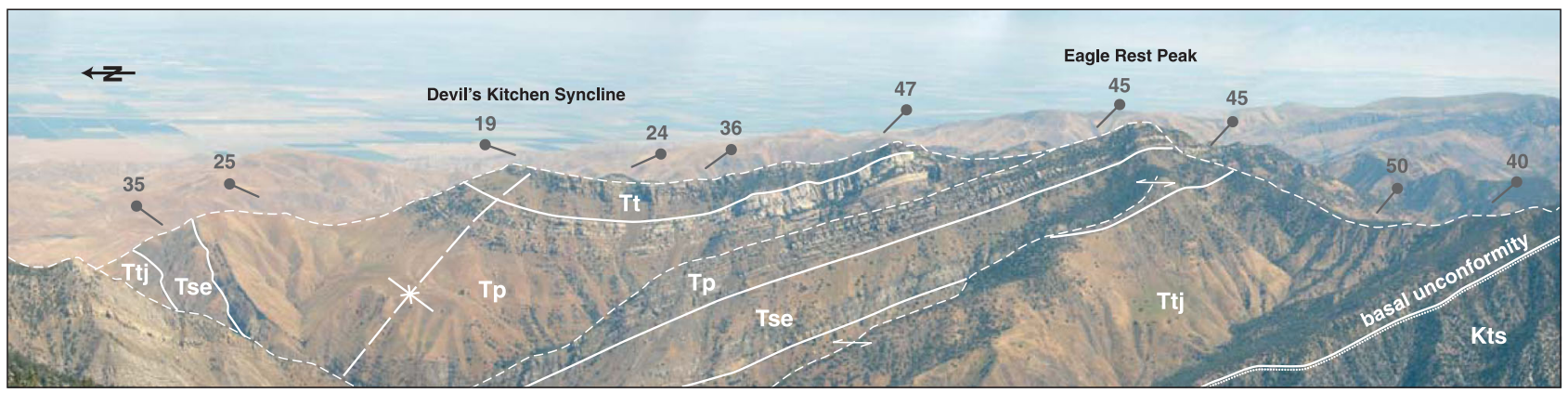

Figure 7. Photograph looking east at the Devil's Kitchen Syncline and Eagle Rest Peak from San Emigdio Mountain (photograph was taken from viewpoint marked in Figure 2). Basal unconformity of Cenozoic sedimentary strata on Cretaceous basement is shown at the lower right of the photograph. Sedimentary strata dip $\sim 45^{\circ} \mathrm{N}$ off of basement toward the San Joaquin Valley, seen in far distance in photograph. Strikes and dips of sedimentary strata, and lithologic contacts, modified from Dibblee [1973] and Ross [1989]. Dashed lines are topographic ridges that may partially obstruct the view. Unit labels as in Figure 2.

igneous and metamorphic rocks, indicating that the Tejon Formation was deposited directly on the basement [Nilsen et al., 1973]. Although this unconformity may have had some amount of relief on it at the time of the Uvas Conglomerate deposition, the position of the San Emigdio Mountains at or near sea level through much of Eocene and Oligocene time suggests that this unconformity can be considered approximately paleohorizontal [Nilsen et al., 1973].

[24] To plot the thermochronologic data with respect to depth below (or distance above), the basal Tertiary unconformity, a plane representing the unconformity above the ground surface was projected from existing geologic maps [Dibblee, 1973]. The strike and dip of the plane were extracted from structural attitude measurements [Dibblee, 1973]. The location of the plane in space was determined from digitization of the basal unconformity from geologic maps [Dibblee, 1973] and extraction of point elevations along this unconformity from the National Elevation Dataset [Gesch et al., 2002]. AHe sample locations were recorded in the field using a handheld GPS receiver. Locations of AFT samples were measured from sample positions recorded on 1:24,000 topographic field maps. The $Z$ coordinates of all samples were defined by intersecting the horizontal sample location with the $1 / 3$ arc sec National Elevation Dataset [Gesch et al., 2002]. The perpendicular distance from each sample location to the unconformity plane was then calculated (Figure 8). Given the natural variation in observed structural attitudes, depth above or below the unconformity was calculated from a dip of $45^{\circ} \pm 5^{\circ}$, and plotted as an error range in the depth estimate (Figure 6b).

[25] Thermochronologic data from the San Emigdios are plotted against distance from the Tertiary basal conformity in two transects, one at the eastern edge of the range, and a second near the center of the range (Figures 2 and 6b). Samples from sedimentary strata in the San Emigdio Mountains are confined to the southern limb of the Devil's Kitchen syncline to avoid potential complications in plotting sample distance and age across a major fold. Although the transect crosses faults in the Mesozoic basement rocks, these faults are unrelated to late Cenozoic development of the San Emigdio Mountains, but reflect instead a period of Late Cretaceous

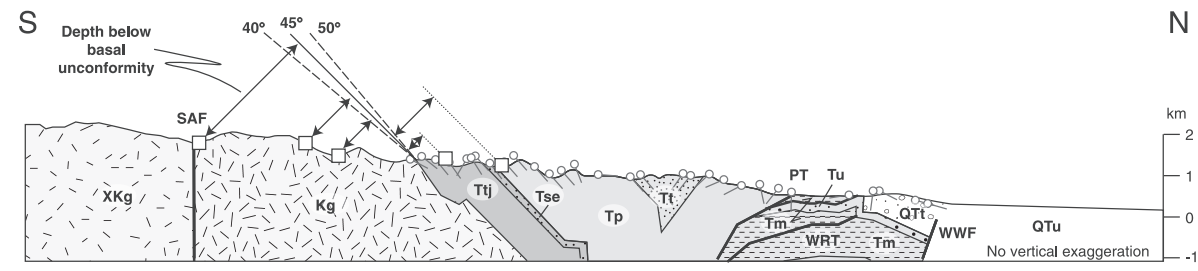

Figure 8. Apatite (U-Th)/He and fission track ages are plotted as distance from the Tertiary basal unconformity in Figure 6b. The base of the Tertiary section in the San Emigdio Mountains is comprised of the Uvas Conglomerate Member of the Tejon Sandstone, and contains clasts of the underlying basement rocks, indicating that it is conformable on the basement [Dibblee, 1973; Nilsen et al., 1973]. The Uvas Conglomerate is present along the base of the Tertiary section from Grapevine Canyon to San Emigdio Canyon (Figure 2), and is overlain by a conformable Tertiary section that dips $\sim 45^{\circ} \mathrm{N}$ (see also Figure 7 ). A three-dimensional plane was fit through the basal unconformity using strike and dip data from published geologic mapping [Dibblee, 1973]. The orthogonal distance from each sample location to this plane was calculated, and error bounds on this distance were determined by calculating the distance from the samples to the plane over a range of dips from $40^{\circ}$ to $50^{\circ}$. Abbreviations as in Figures 1 and 2, with the exception of XKg and $\mathrm{Kg}$, which represent basement rocks generically on the southern and northern sides of the San Andreas, respectively, and QTu, which is undivided Quaternary and Tertiary rocks. Cross section is approximately located along San Emigdio Creek (see Figures 2 and 3) and is modified after [Dibblee, 1961]. 


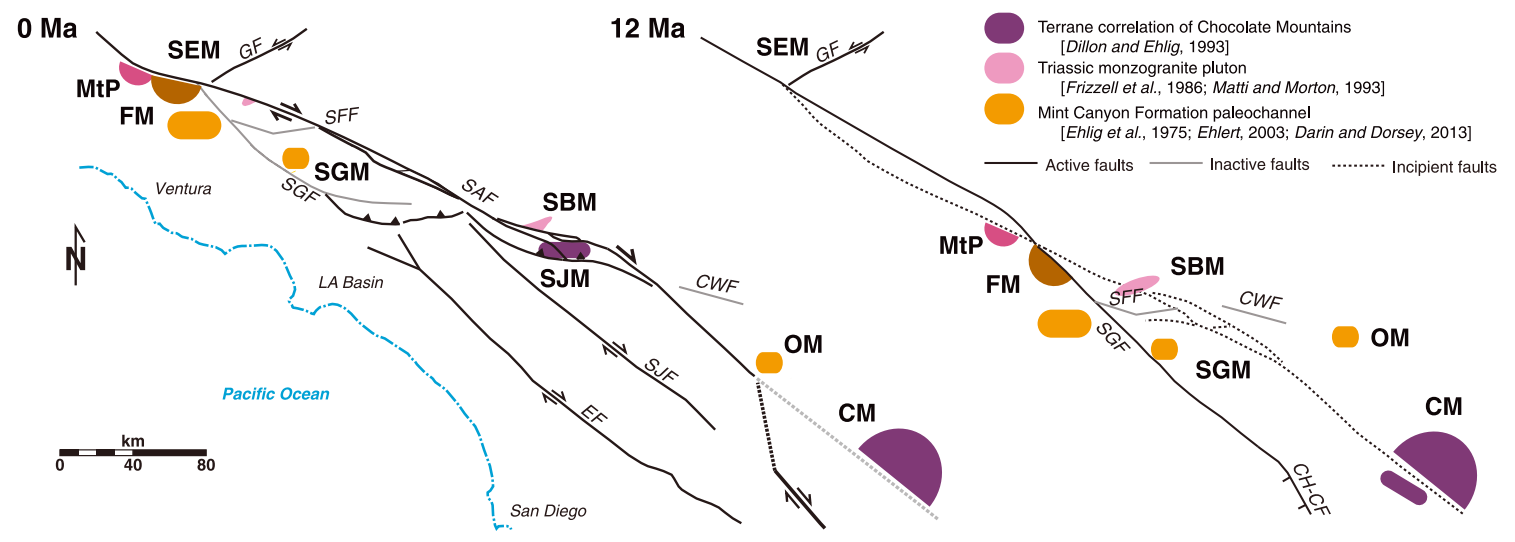

Figure 9. Present active faults of the San Andreas fault system (left) showing the positions of the San Emigdio Mountains, Mount Pinos, and Frazier Mountain, along with key markers used to palinspastically restore motion on the San Andreas fault [e.g., Powell and Weldon, 1992; Matti and Morton, 1993; Powell, 1993], including basement terrane correlations from the Chocolate Mountains [Dillon and Ehlig, 1993], a unique Triassic monzogranite pluton [Frizzell et al., 1986], and the Mint Canyon paleochannel [Ehlig et al., 1975; Ehlert, 2003; Darin and Dorsey, 2013]. Restoration of these markers places Mount Pinos and Frazier Mountain adjacent to the northern San Gabriel Mountains in middle Miocene time (right) [Nourse, 2002] when the San Emigdio Mountains began to be exhumed. Prior to $12 \mathrm{Ma}$, right-lateral slip on the Clemens Well-Fenner-San Francisquito fault placed Proterozoic basement rocks of Frazier Mountain outboard of a trend of similar-aged rocks in the Chocolate and Orocopia Mountains [Powell, 1981]. SEM, San Emigdio Mountains; MtP, Mount Pinos; FM, Frazier Mountain; SGM, San Gabriel Mountains; SBM, San Bernardino Mountains; SJM, San Jacinto Mountain; OM, Orocopia Mountains; and CM, Chocolate Mountains. $C H-C F$, Chino Hills-Cristianitos fault; $C W F$, Clemens Well fault; $E F$, Elsinore fault; $G F$, Garlock fault; $P M F$, Pinto Mountain fault; $S A F$, San Andreas fault; $S F F$, San Francisquito fault; $S G F$, San Gabiel fault; and SJF, San Jacinto fault. Base map of faults modified after Darin and Dorsey [2013].

exhumation of the basement core of the range [e.g., Saleeby et al., 2007; Chapman et al., 2011, 2012].

[26] When plotted in this manner, the age-depth relationships of the thermochronologic data reveal time-temperature path forms associated with crustal cooling and inferred exhumation [e.g., Reiners et al., 2000; Stockli et al., 2000]. Both the eastern (Grapevine Canyon) and central (Salt/San Emigdio/Pleito Creek) transects yield similar patterns of cooling, with apparent burial during Eocene-Miocene time, followed by relatively rapid exhumation from the middle to late Miocene until the present (Figure 6b). The eastern transect along Grapevine Canyon indicates a change in cooling rate in middle Miocene time at approximately $12-13 \mathrm{Ma}$. The central transect appears to continue cooling through the middle Miocene at a constant rate, and then experiences rapid cooling at $\sim 6 \mathrm{Ma}$. The time of change in cooling rate along the central transect is difficult to define, since the two cooling slopes are defined exclusively by separate thermochronometers (the older, slower cooling slope is comprised entirely of AFT ages, while the younger, rapid cooling slope is comprised of $\mathrm{AHe}$ ages; Figure 6b). Thus, the available data constrain recent exhumation of the San Emigdio Mountains to have initiated no earlier than $12 \mathrm{Ma}$, and no later than $\sim 6 \mathrm{Ma}$.

\section{Discussion}

\subsection{Tectonic Implications of Thermochronometric Data}

[27] Geochronologic, thermochronometric, and thermobarometric studies of the igneous rock suite that comprises the basement of the San Emigdio and adjacent Tehachapi mountains reveal relatively high-pressure $(8-10 \mathrm{kbar})$ and high-temperature $\left(590^{\circ}-700^{\circ} \mathrm{C}\right)$ metamorphism of the San Emigdio schist in the San Emigdio Mountains [Chapman et al., 2011]. Rapid exhumation of this schist occurs shortly after peak metamorphic conditions are reached, and the basement of the San Emigdio and Tehachapi mountains is cooled at rates approaching $800^{\circ} \mathrm{C} / \mathrm{Myr}$ at $\sim 80 \mathrm{Ma}$ [Saleeby et al., 2007; Chapman et al., 2012]. This exhumation is postulated to result from the extensional collapse of the southern Sierra Nevada above the underplated Rand, Orocopia, and San Emigdio schists during shallow-slab subduction [Saleeby et al., 2007; Chapman et al., 2010, 2012]. Apatite and zircon (U-Th)/He thermochronometry from the southern Sierra Nevada and Tehachapi mountains indicate that the igneous basement was at shallow crustal levels by early Eocene time [Saleeby et al., 2007; Maheo et al., 2009; Chapman et al., 2012], consistent with deposition of the Uvas Conglomerate Member of the Tejon Formation onto igneous basement in the San Emigdio Mountains in the Eocene (Figure 2) [Dibblee, 1973; Chapman and Saleeby, 2012].

[28] Basin formation and sedimentary deposition continued in the region of the San Emigdio Mountains throughout much of the Cenozoic [e.g., Nilsen et al., 1973], progressively burying the basement. The stratigraphic record of continuous deposition and short mean track lengths clearly implies the development of partial retention and annealing zones in which sample ages are progressively reset with increased burial and heating (Figure 6b) [Stockli et al., 2000]. Samples that display a steep depth-elevation relationship are inferred to record renewed tectonic exhumation of the San Emigdio Mountains in late Miocene time (Figure 6b), 
consistent with a shift to more terrestrial dominated depositional systems in the late Miocene [Kellogg et al., 2008].

[29] Middle to late Miocene exhumation of the San Emigdio Mountains corresponds with a significant reorganization of the Pacific-North America plate boundary. Around $12 \mathrm{Ma}$, transform motion associated with the San Andreas fault system stepped inboard, from the previously active Clemens WellFenner-San Francisquito fault system to the more northerlytrending San Andreas-San Gabriel fault system (Figure 9) [Powell and Weldon, 1992; Matti and Morton, 1993; Powell, 1993]. This reorganization is coincident with the onset of continental extension across the central Basin and Range [Snow and Wernicke, 2000; Niemi et al., 2001] and the establishment of left-lateral slip on the Garlock fault [Burbank and Whistler, 1987; Monastero et al., 1997; Blythe and Longinotti, 2013]. Reorganization of the plate boundary occurred again in the late Miocene, with the abandonment of the San Gabriel strand of the San Andreas fault and the development of the modern plate boundary fault system [Powell and Weldon, 1992], along with the initiation of extension in the Gulf of California [Oskin et al., 2001; Oskin and Stock, 2003], and the onset of deformation in the Eastern California Shear Zone [Dokka and Travis, 1990; Guest et al., 2007; Mahan et al., 2009]. Taken together, these observations suggest that exhumation of the San Emigdio Mountains in late Miocene time was likely driven by the formation and reorganization of the San Andreas fault system, and the evolution of the Big Bend in the San Andreas fault [Bohannon and Howell, 1982], leading to transpression at the southern margin of the San Joaquin Valley.

\subsection{Structural Geometry of the San Emigdio Mountains}

[30] The San Andreas fault has played a central role in the understanding of structural geometries that accommodate transpressional deformation. A critical aspect of such structural models is if and how contractional structures intersect and interact at depth with the primary strike-slip fault [Woodcock and Fischer, 1986]. In many cases, and particularly along the southern San Andreas fault, an antilistric geometry has been proposed, in which reverse or thrust faults that accommodate regional shortening steepen with depth and merge into the main strike-slip fault plane [Sanderson and Marchini, 1984; Sylvester, 1988; Woodcock and Schubert, 1994; Spotila and Sieh, 2000; Woodcock and Rickards, 2003]. Despite both field and analog modeling evidence for the prevalence of such antilistric fault geometries in transpressional settings [e. g., McClay and Bonora, 2001], the existence of a well-developed, apparently thin-skinned fold and thrust belt underlying the San Emigdio Mountains [Namson and Davis, 1988b; Suppe and Medwedeff, 1990; Mueller and Suppe, 1997; Mueller and Talling, 1997; Keller et al., 1998] has led to proposals that the western Transverse Ranges lie above a regional decollement that accommodates shortening throughout the western Transverse Ranges, and into which the San Andreas fault merges (Figure 10) [e. g., Yeats, 1981; Namson and Davis, 1988a]. The low-temperature thermochronometry data presented here offer an opportunity to test the viability of this structural model.

[31] Low-temperature thermochronometry ages north of the San Andreas fault are as young as Pliocene, and imply rapid exhumation over the past few million years. This timing of exhumation of the San Emigdio Mountains is consistent with the timing of shortening across Lockwood Valley, south of the San Andreas fault [Kellogg and Minor, 2005], but the magnitude of exhumation is markedly different on either side of the San Andreas, with Mount Pinos preserving low-temperature thermochronometry ages that reflect regional early Miocene extension. These ages limit post early Miocene exhumation to less than $2-3 \mathrm{~km}$, assuming a paleogeothermal similar to the $30^{\circ} \mathrm{C} / \mathrm{km}$ observed today adjacent to the Mojave strand of the SAF [Lachenbruch et al., 1995]. In contrast, restored depths of samples in the southern San Emigdio Mountains may exceed $5 \mathrm{~km}$, based on structural restoration, the thickness of the Cenozoic sedimentary section, and thermochronometric constraints (Figure 6b). The localization of deformation and exhumation is also quite different on opposing sides of the San Andreas fault. In the San Emigdio Mountains, rapid exhumation and deformation is localized within a few $\mathrm{km}$ of the trace of the San Andreas fault, with progressively less exhumation observed farther north from the San Andreas, and active sediment deposition ongoing in the southern San Joaquin Valley (Figure 2). In contrast, deformation across the Frazier Mountain-Mount Pinos region is widespread, but modest, extending tens of kilometers south of the trace of the San Andreas as broad, open folds in Pliocene sedimentary rocks [Kellogg and Minor, 2005].

[32] These observations strongly suggest that shortening and exhumation of the Frazier Mountain-Mount Pinos region and of the San Emigdio Mountains are not tied to a single, regional decollment (Figure 10a) [Namson and Davis, 1988a]; instead, the structural behavior of the two sides of the San Andreas faults is discrete [e.g., Rust, 1998]. In particular, young thermochronometry ages along the trace of the San Andreas in the San Emigdio Mountains suggest vertical exhumation along the San Andreas itself, consistent with an antilistric fault geometry, in which the vertical component of fault motion would be greatest near the trace of the master strike-slip fault (Figure 10b) [e.g., Spotila and Sieh, 2000]. The distribution of deformation may also be in part controlled by rheologic heterogeneities across the San Andreas fault, as the tectonically dismembered southern Sierra Nevada batholith that comprises the San Emigdio Mountains [Chapman and Saleeby, 2012; Chapman et al., 2012] is compressed between the Proterozoic basement of the Frazier Mountain-Mount Pinos block and the oceanic (?) crust that underlies the southern San Joaquin Valley (Figure 10b). However, the overall geometry of transpressional faults in the western Transverse Ranges appears to conform broadly to the antilistric geometries that have been proposed for the southern San Andreas fault in the eastern Transverse Ranges [e.g., Sylvester, 1988], implying that this is a common feature of transpressional tectonics throughout the Big Bend region of the San Andreas fault.

\subsection{Strain Partitioning in the Western Transverse Ranges}

[33] The increase in rock uplift toward the San Andreas fault in the San Emigdio Mountains mimics a commonly observed pattern of vertical deformation associated with transpression. Concentrations of rugged topography and exhumation occur along much of the San Andreas fault zone [Spotila et al., 2007b, 2007a], as well as other continental transforms, including the Denali fault [Fitzgerald et al., 1993], Alpine fault 

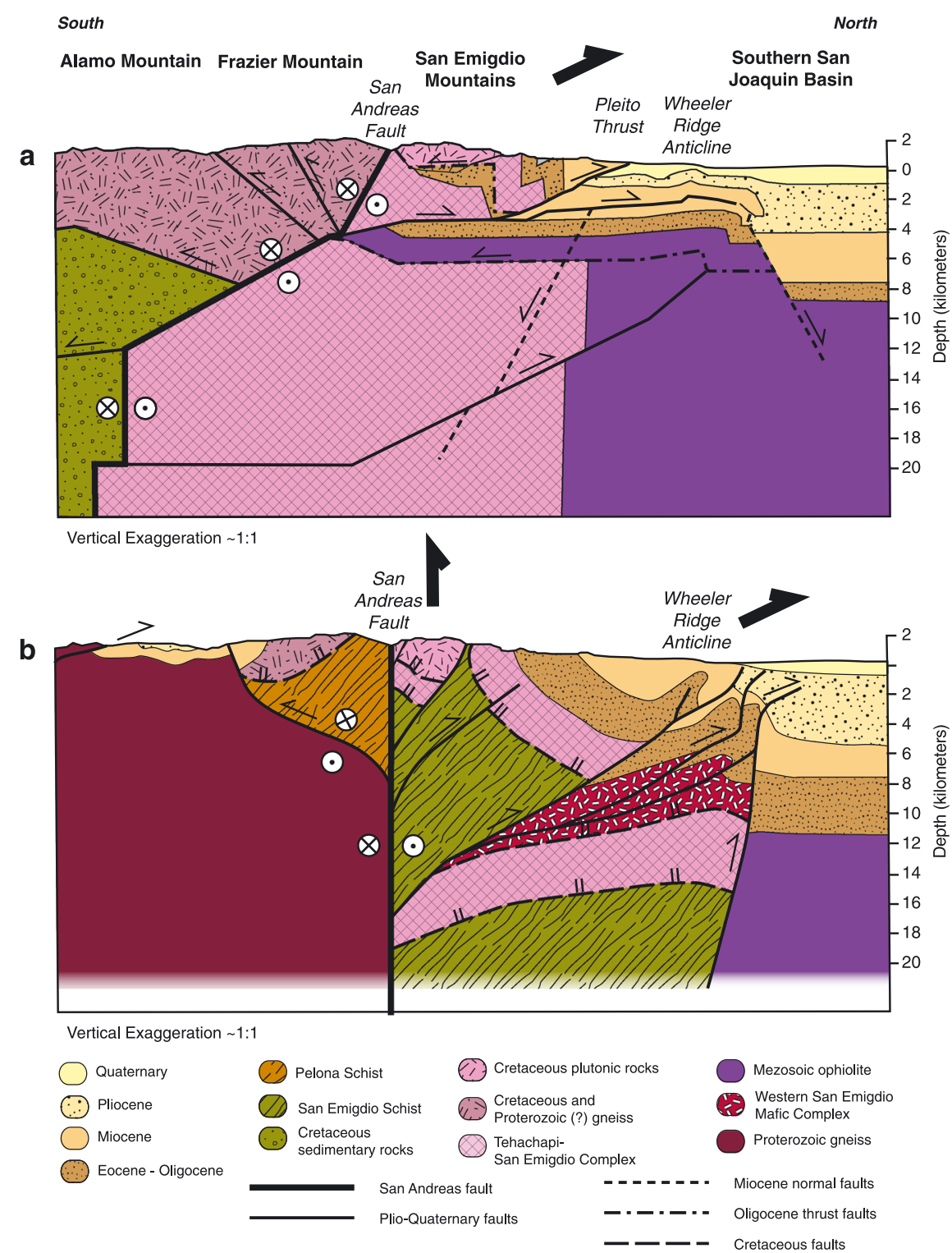

Figure 10. Cross sections through the San Emigdio Mountains showing representations of the interactions between thrust faults and the San Andreas fault at depth. (a) A cross section modified after Namson and Davis [1988a] showing thrust faults soling into a master detachment fault that offsets the San Andreas fault and continues southward under the Los Angeles Basin. (b) An alternate representation in which deformation is largely confined to a wedge north of the San Andreas fault that is sandwiched between rigid lithospheric blocks comprised of Proterozoic gneiss (to the south) and Mesozoic ophiolite (to the north; see text for discussion). This schematic cross section is consistent with significant differences in exhumation history across the San Andreas fault, as demonstrated by low-temperature thermochronologic data, and implies an inverse flower-structure geometry with the San Emigdios being pushed northward over the southern edge of the San Joaquin Valley. The cross section is located approximately along Grapevine Canyon (see Figures 2 and 3) and is modified from interpretations and data published by Chapman and Saleeby [2012], Goodman and Malin [1992], and Kellogg [2003].

[Tippett and Kamp, 1993], and Karakoram fault [Foster et al., 1994]. These field examples fit with experimental and theoretical studies that predict intense vertical deformation will be narrowly focused within transpressive fault zones [Wilcox et al., 1973; Fossen and Tikoff, 1998]. Near-field rock uplift along strike-slip faults results in combination from the mechanics of wrenching and strain-partitioning [Tikoff and Teyssier, 1994; Spotila et al., 2007a], as well as secondary deformation due to geometric irregularities along the fault trace [Cowgill et al., 2004a; Wakabayashi et al., 2004; Buscher and Spotila, 2007].

[34] The pattern of rock uplift and style of deformation in the San Emigdio Mountains are very similar to the pattern observed in the San Bernardino Mountains, farther south along the San Andreas fault [Spotila et al., 1998]. In both cases, rock uplift increases both toward the fault and toward 
the apex of the fault bend, resulting in a symmetrical bullseye pattern of vertical strain (as inferred from cooling ages; Figure 3). As in the San Emigdio Mountains, basement rock uplift in the San Bernardino Mountains has been accomplished via antilistric thrust faults that steepen toward the San Andreas fault, merging with it at depth into a crustalscale flower structure [Spotila and Sieh, 2000]. A key difference in the San Emigdio Mountains, however, is the presence of the thick on-lapped Cenozoic sedimentary sequence, which enables more confident reconstruction of the flowerstructure geometry (Figure 10b). The antilistric geometry is consistent with the conceptual model of flower or palmshaped structures that are predicted to be the typical mode of uplift along strike-slip faults [Sanderson and Marchini, 1984; Sylvester, 1988; Woodcock and Schubert, 1994; Woodcock and Rickards, 2003].

[35] The primary far-field driver of vertical deformation in the San Emigdio Mountains is likely the obliquity to plate motion of this segment of the San Andreas fault. The trace of the fault through the San Emigdio Big Bend is on average $37^{\circ}$, convergently oblique to far-field plate motion [Spotila et al., 2007b], thus creating a pure shear-dominated condition that is ideal for strain partitioning and concentrated near-field rock uplift [Tikoff and Teyssier, 1994; Fossen and Tikoff, 1998]. An additional driver of shortening along this segment may be the slip transfer from the intersecting Garlock fault. If left slip along the Garlock fault does not decay rapidly enough to the west, this slip could induce convergence north of the intersection in the San Emigdio Mountains and divergence along the Mojave segment of the San Andreas fault to the southeast (Figure 1). This pattern of faulting mimics that observed in the San Bernardino Mountains, where the focused bulls-eye of rock uplift occurs at the apex of the fault bend north of San Gorgonio Pass, $\sim 15 \mathrm{~km}$ northwest of the intersection of the left-lateral Pinto Mountain fault [Spotila and Sieh, 2000]. This is geometrically similar to what we observed in the San Emigdio Mountains, where significant exhumation occurs along the San Emigdio Creek transect, at the apex of a small inflection in the trace of the San Andreas fault, approximately $15 \mathrm{~km}$ west of the intersection with the Garlock. Without detailed slip-rate data along the conjugate left-lateral faults, however, the magnitude of excess strain associated with the fault intersections cannot be readily determined.

[36] If the highly convergent fault bends and focused rock uplift in the San Emigdio and San Bernardino Mountains are, in fact, partially driven by the intersection with the conjugate left-lateral faults, this implies that the loci of transpression have been fixed relative to the structural geometries situated to the east of the San Andreas fault zone [Spotila and Sieh, 2000]. In other words, the welts of deforming crust would remain pinned to the fault confluence and associated bends since the onset of deformation in the late Miocene, rather than migrating away from the bend to the southeast. The abrupt southeastern boundary of transpressive deformation in the San Emigdio Mountains is consistent with this kinematic interpretation (Figure 3). This differs from the pattern of transpressional deformation in the Santa Cruz Mountains farther north along the San Andreas fault, where deformed crust on either side of the fault is interpreted to translate bilaterally away from the bend, resulting in trailing, decaying mountain ranges to the northwest and southeast [Anderson,
1990]; although models wherein one side of the Santa Cruz Mountains is fixed relative to the fault have also been proposed [Bürgmann et al., 1994].

[37] An additional control on transpressive deformation along the San Emigdio Mountains may be lithosphere-scale mechanical heterogeneity. The stark difference in the pattern of transpressive deformation on either side of the San Andreas fault may be linked to differing crustal rheologies. Whereas there is a tight concentration of rock uplift in the San Emigdio Mountains immediately adjacent to the SAF that is temporally linked to SAF evolution, no such Late Miocene deformation is observed to the southwest of the San Andreas fault, based on our limited data. Convergent deformation since the late Miocene has been broadly distributed over tens of kilometers along thrust faults and low-amplitude folds in the Lockwood Valley area [Kellogg and Minor, 2005]. The topographic welts that occur in this area (Mount Pinos and Frazier Mountain) do not coincide with zones of focused exhumation. This difference may stem from the mechanical response of distinct rock types on either side of the San Andreas fault. To the southwest, the crust consists of Mesozoic Peninsular Ranges batholith intruded into Proterozoic gneiss with crustal affinities to the Chocolate and Orocopia Mountains. This relatively strong group of rock types consists of homogeneous, undeformed plutons intruded into old, cold basement. This package is then stacked atop Cretaceous Pelona/Rand schist via the Vincent thrust [Namson and Davis, 1988a] (Figure 10), which may impart a tendency to fail along broad, low-angle, regional decollements due to fault reactivation. In contrast, the San Emigdio block consists of a narrow slice of southern Sierran basement, consisting of tonalite and mafic gneiss. The San Emigdio block represents reconstructed lithosphere that experienced Late Cretaceous extensional collapse and underplating, and thus may be warm and weak [Chapman et al., 2010]. This narrow strip of southern Sierran basement is sandwiched between the San Andreas fault and the southern San Joaquin Valley, which is likely underlain by strong ophiolitic oceanic lithosphere or transitional crust related to back-arc spreading [Holbrook and Mooney, 1987; Goodman and Malin, 1992]. We hypothesize that the San Emigdio Mountains have been more intensely deformed, because they are weaker than the lithospheric blocks that bound them to the north and south. Eventually, the narrow San Emigdio sliver will be fully exhumed due to San Andreas fault transpression, resulting in collision of the strong Pinos block and San Joaquin Valley and a concomitant structural reorganization.

[38] The potential role of lithospheric heterogeneity in dictating patterns of strain along the San Andreas fault is an intriguing example of the influence of material properties on tectonic deformation. Preexisting weaknesses are well known to influence structural patterns in various tectonic regimes. For example, the geometry of ancient orogenic belts is known to influence the location of crustal rifts (and vice versa) [Dunbar and Sawyer, 1989; Ring, 1994; Vauchez et al., 1997; Corti et al., 2007] In this case, patterns of previous deformation influence subsequent deformation, due to the damage imparted on the lithosphere. In the case of the San Emigdio Mountains, it is not preexisting structure, but rather an optimal orientation of a weaker package of rock that may be dictating deformation. In this sense, it may be more analogous to how weak stratigraphy (e.g., shale, halite, and 
anhydrite) controls the formation of regional decollments in fold and thrust belts, such as the Zagros Mountains [Sherkati et al., 2006]. Unlike foreland thrust belts, which by their nature tend to form in mechanically stratified material, our proposed tectonic inheritance along the San Andreas fault may be more circumstantial, depending on a unique juxtaposition of weaker and stronger vertical packages of rock. Still, it illustrates that lithospheric heterogeneity may impart an added complex control on the nature of deformation associated with transpressive continental transforms.

\section{Conclusions}

[39] Low-temperature thermochronometry data from the western Transverse Ranges record rapid exhumation in late Miocene time in the San Emigdio Mountains, north of the Big Bend of the San Andreas fault, consistent with active shortening and exhumation of the range by thrusting over the southern margin of the San Joaquin Valley. This pattern and timing of deformation contrasts with observations from the southern side of the San Andreas fault in the Mount Pinos and Frazier Mountain regions, where low-temperature thermochronometry data record early Miocene cooling, presumed to result from regional extension in southern California at that time. These data suggest that transpressional deformation is effectively decoupled between the two sides of the San Andreas fault, and that shortening associated with transpression in the western Transverse Ranges is accommodated almost solely within the San Emigdio Mountains. Such an asymmetric deformation field is commonly observed in transpressional settings, and may be a key feature that permits accommodation of oblique convergence. Rheologic heterogeneity may play an important role in this strain localization, as the relatively weak, previously extended and deeply exhumed crust of the San Emigdio Mountains is squeezed between Proterozoic basement of the Frazier Mountain and Mount Pinos block, and the oceanic or transitional crust that underlies the southern San Joaquin Valley. Such a pattern of deformation affords an explanation for the antilistric fault geometries observed and implies that the western Big Bend of the San Andreas is moving northward with continued convergence such that the San Emigdio Mountains may eventually be completely exhumed along the San Andreas fault.

\section{Appendix A: Analytical Methods}

\section{A1. (U-Th)/He Analysis}

[40] Samples for AHe analysis were collected from plutonic and metamorphic rocks, primarily granitoids, that yielded relatively large, euhedral apatite crystals. Apatite grains for $\mathrm{AHe}$ analysis were handpicked from mineral separates produced using standard density and magnetic techniques prepared by Apatite to Zircon, Inc. Prior to analysis, apatite grains were selected on the basis of euhedral morphology and were scanned for visible inclusions of high $\mathrm{U}$ or Th-rich phases under a 120 times binocular microscope using crossed polars. Grains were also measured for alpha-ejection correction [Farley et al., 1996]. A mass-weighted average grain radius was determined for the alpha-ejection correction for aliquots containing multiple grains. Analyses of multigrain aliquots (Table A1) were undertaken at Virginia Tech. These aliquots were outgassed in a resistance furnace at $940^{\circ} \mathrm{C}$ for $20 \mathrm{~min}$ and analyzed for ${ }^{4} \mathrm{He}$ by ${ }^{3} \mathrm{He}$ spike and quadrupole mass spectrometry. Analyses of single grains were undertaken at Caltech. Laser heating was performed to outgas helium following the methods of House et al. [2000] and McDowell et al. [2005]. $\mathrm{U}$ and Th concentrations were measured at Yale University for samples outgassed at Virginia Tech and at Caltech for samples outgassed at Caltech by inductively coupled plasma mass spectrometry following apatite grain dissolution and application of a spike containing ${ }^{235} \mathrm{U}$ and ${ }^{230} \mathrm{Th}$. Replicate analyses were conducted to the limit of apatite quantity and quality, with a minimum of two replicates analyzed for each sample (Table A1). Errors in the He ages are based on propagation of the analytical uncertainties in $\mathrm{U}, \mathrm{Th}$, and He measurements and are reported as $3 \%(1 \sigma)$ based on the reproducibility of laboratory standards [Farley, 2000, 2002]. Errors on mean ages are reported at $1 \sigma$ as standard errors. The standard error is larger than the analytical error alone and reflects uncertainties due to nonanalytical sources, such as grain size variation and zonation and other factors that may contribute to uncertainties in the alpha-ejection correction [e.g., House et al., 2001; Farley and Stockli, 2002]. Age accuracy was checked by measurement of known standards, including Durango fluorapatite with a known age of $31.4 \mathrm{Ma}$ [McDowell et al., 2005]. Four out of a total of 60 replicate analyses were excluded from mean age determinations (Table A1). These analyses were presumably contaminated by excess ${ }^{4} \mathrm{He}$ derived from undetected U- and Th-rich inclusions.

\section{A2. Fission Track Analysis}

[41] Apatite and zircon separates for fission track analyses were prepared from subsurface samples at Southern Methodist University using standard heavy liquid and magnetic separation techniques. Separates from surface samples were produced by Geochron Laboratories. Most of the samples yielded sufficient quantities of apatite and zircon for fission track dating purposes.

[42] Samples containing sufficient material were prepared for fission track dating following the external detector method (EDM) of Naeser [1979]. Apatite grains were mounted in an epoxy wafer, polished to expose the grains, and etched for $25 \mathrm{~s}$ in a $5 \mathrm{M}$ solution of nitric acid to reveal the fission tracks. The slides were examined to assess polish and etch quality. The apatite grain mounts were covered with muscovite detectors and placed in a reactor package with Durango apatite (Baron collection) and Mount Dromedary apatite age standards, and NBS (SRM 962) and Corning (CN-6) fission track glass standards (Table A2). Zircon grains were mounted in FEP Teflon tape, polished to expose the grains, and etched in a sodium hydroxide-potassium hydroxide mixture at $230^{\circ} \mathrm{C}$. In a number of cases, multiple zircon populations (recognized on the basis of morphology and etching characteristics) were present within a sample. Multiple mounts were made and each mount was etched for a different amount of time in an attempt to attain optimum etch conditions for each population. The zircon grain mounts were covered with muscovite detectors and placed in a reactor package with Fish Canyon, Mount Warning, and Mount Dromedary zircon age standards, and NBS (SRM 692) and Corning (CN-5) fission track glass standards (Table A3).

[43] Fiduciary holes were punched through the muscovite detectors into the EDM mounts with a microprobe needle 
Table A1. (U-Th)/He Raw Analyses ${ }^{\mathrm{a}}$

\begin{tabular}{|c|c|c|c|c|c|c|c|c|c|c|c|}
\hline Sample & $\begin{array}{l}\text { No. } \\
\text { Grains }\end{array}$ & $\begin{array}{c}\mathrm{U} \\
(\mathrm{ppm})\end{array}$ & $\begin{array}{c}\text { Th } \\
\text { (ppm) }\end{array}$ & $\begin{array}{c}\mathrm{He} \\
(\mathrm{nmol} / \mathrm{g})\end{array}$ & $\begin{array}{l}\text { Radius } \\
(\mu \mathrm{m})\end{array}$ & $\begin{array}{l}\text { Length } \\
(\mu \mathrm{m})\end{array}$ & $\begin{array}{l}\text { Mass } \\
(\mathrm{g})\end{array}$ & $F_{t}$ & $\begin{array}{l}\text { Raw Age } \\
\text { (Ma) }\end{array}$ & $\begin{array}{l}\text { Corr. Age } \\
\text { (Ma) }\end{array}$ & $\begin{array}{l}\text { Error } \\
(1 \sigma)\end{array}$ \\
\hline EMIG-1(c) & 1 & 4.9 & 0.4 & 0.118 & 46 & 184 & 4 & 0.73 & 4.3 & 5.9 & 0.2 \\
\hline EMIG-1(d) & 1 & 5.6 & 1.0 & 0.056 & 55 & 189 & 9 & 0.76 & 1.9 & 2.5 & 0.1 \\
\hline TG-1(a) & 4 & 94.3 & 46.8 & 3.064 & 44 & 266 & 11 & 0.71 & 5.4 & 7.5 & 0.2 \\
\hline TG-1(b) & 4 & 99.8 & 51.6 & 3.303 & 49 & 234 & 12 & 0.73 & 5.4 & 7.4 & 0.2 \\
\hline TG-2(a) & 4 & 42.1 & 24.7 & 0.898 & 59 & 223 & 16 & 0.76 & 3.5 & 4.5 & 0.1 \\
\hline TG-2(b) & 5 & 68.5 & 24.2 & 3.862 & 53 & 250 & 19 & 0.75 & 9.6 & 12.8 & 0.4 \\
\hline TG-3(a) & 4 & 65.3 & 25.0 & 1.858 & 51 & 210 & 12 & 0.74 & 4.8 & 6.5 & 0.2 \\
\hline TG-3(b) & 4 & 74.6 & 24.9 & 1.537 & 47 & 191 & 9 & 0.72 & 3.5 & 4.9 & 0.1 \\
\hline TG-5(a) & 4 & 52.2 & 14.3 & 2.490 & 51 & 206 & 11 & 0.73 & 8.2 & 11.2 & 0.3 \\
\hline TG-5(b) & 4 & 81.6 & 31.4 & 4.373 & 54 & 219 & 14 & 0.75 & 9.0 & 12.1 & 0.4 \\
\hline TG-7(a) & 3 & 110.2 & 6.8 & 18.454 & 52 & 234 & 10 & 0.75 & 30.3 & 40.6 & 1.2 \\
\hline TG-7(b) & 2 & 73.9 & 4.0 & 11.227 & 51 & 253 & 8 & 0.75 & 27.5 & 36.5 & 1.1 \\
\hline TG-8(a) & 4 & 33.1 & 2.2 & 8.491 & 58 & 272 & 20 & 0.77 & 46.2 & 59.9 & 1.8 \\
\hline TG-8(b) & 3 & 36.6 & 2.4 & 8.873 & 54 & 223 & 11 & 0.75 & 43.7 & 58.1 & 1.7 \\
\hline NNGR-1(a) & 4 & 22.1 & 5.3 & 5.721 & 61 & 283 & 22 & 0.78 & 44.9 & 57.6 & 1.7 \\
\hline NNGR-1(b) & 4 & 18.2 & 3.0 & 4.317 & 63 & 223 & 19 & 0.78 & 41.8 & 53.7 & 1.6 \\
\hline NNGR-5(a) & 3 & 34.2 & 40.4 & 2.306 & 54 & 289 & 14 & 0.76 & 9.7 & 12.8 & 0.4 \\
\hline NNGR-5(b) & 3 & 29.2 & 31.6 & 1.861 & 49 & 200 & 7 & 0.72 & 9.4 & 13.1 & 0.4 \\
\hline NNGR-6(a) & 2 & 26.8 & 51.5 & 2.274 & 47 & 193 & 5 & 0.71 & 10.8 & 15.2 & 0.5 \\
\hline NNGR-6(b) & 3 & 23.4 & 29.9 & 1.107 & 40 & 166 & 4 & 0.67 & 6.7 & 10.0 & 0.3 \\
\hline NNSC-1(a) & 3 & 41.2 & 38.1 & 1.095 & 57 & 240 & 13 & 0.76 & 4.0 & 5.3 & 0.2 \\
\hline NNSC-1(b) & 3 & 60.0 & 52.8 & 1.457 & 55 & 223 & 11 & 0.75 & 3.7 & 4.9 & 0.1 \\
\hline NNSE-2(a) & 3 & 24.1 & 5.0 & 0.501 & 53 & 169 & 8 & 0.74 & 3.6 & 4.9 & 0.1 \\
\hline NNSE-2(b) & 3 & 16.0 & 3.7 & 0.260 & 57 & 171 & 9 & 0.75 & 2.8 & 3.8 & 0.1 \\
\hline NNSE-3(a) & 1 & 3.8 & 0.6 & 0.066 & 51 & 180 & 3 & 0.73 & 3.1 & 4.2 & 0.1 \\
\hline NNSE-3(b) & 1 & 36.6 & 4.1 & 0.943 & 51 & 266 & 4 & 0.75 & 4.6 & 6.2 & 0.2 \\
\hline NNSE-4(a) & 2 & 7.0 & 5.3 & 0.186 & 51 & 214 & 6 & 0.74 & 4.2 & 5.6 & 0.2 \\
\hline NNSE-4(b) & 2 & 3.7 & 3.6 & 0.065 & 50 & 214 & 6 & 0.73 & 2.6 & 3.6 & 0.1 \\
\hline NNSE-4(c) & 1 & 4.6 & 5.6 & 0.102 & 74 & 171 & 5 & 0.79 & 3.2 & 4.0 & 0.1 \\
\hline NNSE-5(a) & 3 & 132.7 & 124.7 & 4.496 & 62 & 274 & 17 & 0.78 & 5.1 & 6.6 & 0.2 \\
\hline NNSE-5(b) & 4 & 99.2 & 89.5 & 3.412 & 60 & 251 & 20 & 0.77 & 5.2 & 6.7 & 0.2 \\
\hline SEGR-9(a) ${ }^{b}$ & 1 & 69.8 & 32.5 & 2.625 & 40 & 266 & 2 & 0.69 & 6.2 & 9.1 & 0.3 \\
\hline SEGR-9(b) & 1 & 22.6 & 9.6 & 0.686 & 49 & 214 & 3 & 0.73 & 5.1 & 7.0 & 0.2 \\
\hline SEGR-9(c) & 1 & 33.8 & 11.1 & 0.976 & 43 & 257 & 3 & 0.71 & 4.9 & 7.0 & 0.2 \\
\hline SEGR-9(d) & 1 & 51.1 & 19.4 & 1.644 & 46 & 240 & 3 & 0.72 & 5.4 & 7.6 & 0.2 \\
\hline SEGR-9(e) & 1 & 47.8 & 22.6 & 1.686 & 40 & 240 & 2 & 0.69 & 5.8 & 8.5 & 0.3 \\
\hline SEGR-9(f) & 1 & 33.5 & 14.2 & 1.159 & 40 & 206 & 2 & 0.68 & 5.8 & 8.5 & 0.3 \\
\hline SEGR-10(a) & 1 & 5.5 & 10.3 & 0.352 & 43 & 231 & 2 & 0.69 & 8.2 & 11.8 & 0.4 \\
\hline SEGR-10(b) & 1 & 28.4 & 12.7 & 2.333 & 40 & 240 & 2 & 0.69 & 13.7 & 19.9 & 0.6 \\
\hline SEGR-10(c) & 1 & 6.5 & 7.4 & 0.266 & 40 & 137 & 1 & 0.65 & 5.9 & 9.1 & 0.3 \\
\hline SEGR-10(d) & 1 & 7.6 & 8.3 & 0.331 & 43 & 206 & 2 & 0.69 & 6.4 & 9.3 & 0.3 \\
\hline SEGR-10(e) ${ }^{b}$ & 1 & 9.5 & 6.5 & 1.017 & 40 & 197 & 2 & 0.68 & 17.0 & 25.1 & 0.8 \\
\hline SEGR-10(f) & 1 & 2.6 & 2.8 & 0.106 & 54 & 171 & 3 & 0.73 & 5.9 & 8.1 & 0.2 \\
\hline PINOS-1(a) & 1 & 23.4 & 11.2 & 4.097 & 50 & 214 & 12 & 0.75 & 28.9 & 38.6 & 1.2 \\
\hline PINOS-1(b) & 1 & 11.3 & 6.6 & 2.048 & 54 & 210 & 13 & 0.76 & 29.3 & 38.4 & 1.2 \\
\hline PINOS-1(c) & 1 & 25.2 & 7.4 & 4.514 & 59 & 251 & 18 & 0.79 & 30.7 & 39.1 & 1.2 \\
\hline PINOS-1(d) & 1 & 4.1 & 2.4 & 0.712 & 70 & 210 & 22 & 0.81 & 27.9 & 34.7 & 1.0 \\
\hline PINOS-2(a) & 1 & 54.9 & 114.0 & 8.391 & 59 & 251 & 14 & 0.79 & 18.9 & 23.9 & 0.7 \\
\hline PINOS-2(b) & 1 & 24.0 & 37.7 & 3.318 & 76 & 280 & 26 & 0.83 & 18.5 & 22.4 & 0.7 \\
\hline PINOS-3(a) & 1 & 39.6 & 30.3 & 2.439 & 91 & 287 & 26 & 0.85 & 9.6 & 11.3 & 0.3 \\
\hline PINOS-3(b) & 1 & 61.4 & 44.4 & 6.588 & 61 & 266 & 16 & 0.79 & 16.8 & 21.2 & 0.6 \\
\hline PINOS-3(c) & 1 & 49.0 & 36.3 & 6.333 & 70 & 314 & 25 & 0.82 & 20.2 & 24.6 & 0.7 \\
\hline PINOS-4(a) & 1 & 23.2 & 44.1 & 3.713 & 61 & 298 & 24 & 0.80 & 20.4 & 25.5 & 0.8 \\
\hline PINOS-4(b) & 1 & 24.7 & 46.4 & 4.534 & 70 & 297 & 24 & 0.82 & 23.4 & 28.5 & 0.9 \\
\hline PINOS-5(a) & 1 & 21.1 & 17.2 & 2.417 & 62 & 257 & 16 & 0.80 & 17.7 & 22.2 & 0.7 \\
\hline PINOS-5(b) & 1 & 21.9 & 15.4 & 2.494 & 68 & 251 & 19 & 0.81 & 18.0 & 22.2 & 0.7 \\
\hline PINOS-5(c) & 1 & 23.1 & 16.4 & 2.548 & 72 & 334 & 28 & 0.83 & 17.4 & 21.0 & 0.6 \\
\hline PINOS-5(d) & 1 & 21.0 & 14.8 & 2.503 & 89 & 266 & 22 & 0.85 & 18.8 & 22.2 & 0.7 \\
\hline PINOS-6(a) & 1 & 4.7 & 20.3 & 0.854 & 61 & 257 & 20 & 0.79 & 16.5 & 20.8 & 0.6 \\
\hline PINOS-6(b) & 1 & 7.5 & 31.9 & 1.504 & 71 & 253 & 28 & 0.82 & 18.4 & 22.5 & 0.7 \\
\hline
\end{tabular}

${ }^{\mathrm{a}}$ Samples were laser heated at the California Institute of Technology, Pasadena (Caltech) Noble Gas Laboratory following methods outlined in House et al. [2000] and McDowell et al. [2005]. Helium ages are corrected for alpha ejection [Farley et al., 1996]. U and Th concentrations are computed from sample mass calculated from grain size measurements or from Ca concentration. $F_{t}$ is a mass-weighted value [Farley et al., 1996]. Errors on single replicate analyses are $6 \%(2 \sigma)$ and represent uncertainty on reproducibility of laboratory standards [Farley, 2000; Farley, 2002].

${ }^{\mathrm{b}}$ These replicates were excluded from calculations of the mean age of samples in Table 1. 
Table A2. Apatite Fission Track Raw Data ${ }^{a}$

\begin{tabular}{|c|c|c|c|c|c|c|c|c|c|c|}
\hline Sample & $\begin{array}{l}\text { No. } \\
\text { grains }\end{array}$ & $\begin{array}{l}\rho_{s} \times 10^{5} \\
\left(\mathrm{t} / \mathrm{cm}^{2}\right)\end{array}$ & $\mathrm{N}_{s}$ & $\begin{array}{l}\rho_{i} \times 10^{6} \\
\left(\mathrm{t} / \mathrm{cm}^{2}\right)\end{array}$ & $\mathrm{N}_{i}$ & $\begin{array}{l}\rho_{d} \times 10^{6} \\
\left(\mathrm{t} / \mathrm{cm}^{2}\right)\end{array}$ & $\mathrm{N}_{d}$ & $\begin{array}{c}\mathrm{U} \\
(\mathrm{ppm})\end{array}$ & $\begin{array}{l}\mathrm{P}\left(\chi^{2}\right) \\
(\%)\end{array}$ & $\begin{array}{c}\text { Mean Track Length } \\
\mu \mathrm{m} \pm 1 \sigma(\mathrm{n})\end{array}$ \\
\hline \multicolumn{11}{|c|}{ Surface Samples } \\
\hline PLC-1-89 & 20 & 2.86 & 263 & 5.62 & 2586 & 2.497 & 4610 & 12 & 99 & $12.7 \pm 1.5(100)$ \\
\hline PLC-2-89 & 20 & 1.47 & 141 & 3.08 & 1479 & 2.480 & 4610 & 7 & 99 & $12.8 \pm 1.3(100)$ \\
\hline PLC-3-89 & 20 & 1.02 & 43 & 4.51 & 947 & 2.501 & 4610 & 10 & 99 & $13.5 \pm 0.9(8)$ \\
\hline PLC-4-89 & 20 & 1.64 & 167 & 3.29 & 1680 & 2.516 & 4610 & 7 & 99 & $12.1 \pm 1.7(101)$ \\
\hline PLC-5-89 & 20 & 2.66 & 149 & 4.87 & 1365 & 2.532 & 4610 & 10 & 95 & $12.4 \pm 1.7(115)$ \\
\hline PLC-6-89 & 20 & 1.79 & 208 & 4.32 & 2507 & 2.534 & 4610 & 9 & 50 & $11.9 \pm 1.9(103)$ \\
\hline PLC-7-89 & 20 & 0.59 & 75 & 3.94 & 2481 & 2.547 & 4610 & 8 & 85 & $10.5 \pm 2.5(6)$ \\
\hline PLC-8-89 & 20 & 0.36 & 58 & 3.04 & 2431 & 2.579 & 4610 & 6 & 99 & $13.9 \pm 2.5(32)$ \\
\hline DK-1-89 & 20 & 1.68 & 74 & 7.82 & 1722 & 2.572 & 4610 & 17 & 60 & $12.5 \pm 2.1(100)$ \\
\hline DK-2-89 & 20 & 1.52 & 82 & 7.34 & 1981 & 2.588 & 4610 & 15 & $<1$ & $12.5 \pm 2.1(51)$ \\
\hline DK-3-89 & 20 & 1.60 & 144 & 3.28 & 1474 & 2.601 & 4610 & 7 & 98 & $12.3 \pm 2.0(100)$ \\
\hline DK-4-89 & 20 & 1.01 & 99 & 5.76 & 2823 & 2.616 & 4610 & 12 & $<1$ & $12.3 \pm 2.5(63)$ \\
\hline DK-5-89 & 20 & 1.55 & 130 & 5.90 & 2479 & 2.619 & 4610 & 14 & 45 & $11.8 \pm 2.2(100)$ \\
\hline DK-6-89 & 20 & 1.33 & 104 & 8.05 & 3140 & 2.632 & 4610 & 17 & $<1$ & $12.1 \pm 2.3(100)$ \\
\hline DK-7-89 & 20 & 1.42 & 94 & 5.14 & 1695 & 2.651 & 4610 & 10 & $<1$ & $11.9 \pm 2.3(90)$ \\
\hline DK-8-89 & 20 & 0.91 & 97 & 8.59 & 4551 & 2.673 & 4610 & 17 & $<1$ & $12.3 \pm 2.5(52)$ \\
\hline DK-10-89 & 20 & 1.06 & 51 & 7.16 & 1714 & 2.662 & 4610 & 15 & 30 & $12.1 \pm 2.2(3)$ \\
\hline DK-11-89 & 20 & 0.66 & 77 & 6.06 & 3512 & 2.690 & 4610 & 12 & $<1$ & $12.6 \pm 2.3(83)$ \\
\hline DK-12-89 & 20 & 0.18 & 24 & 1.02 & 691 & 2.707 & 4610 & 2 & 99 & N.D. \\
\hline \multicolumn{11}{|c|}{ Subsurface Samples } \\
\hline B1 9455-61 & 20 & 1.17 & 77 & 1.64 & 539 & 1.799 & 5400 & 5 & 97 & $12.8 \pm 1.6(35)$ \\
\hline B1 12753-78 & 20 & 1.65 & 135 & 2.36 & 969 & 1.799 & 5400 & 7 & 99 & $10.1 \pm 2.1(100)$ \\
\hline B1 14040 & 3 & 0.87 & 7 & 1.55 & 62 & 1.802 & 5400 & 5 & 90 & $12.8 \pm 1.6(2)$ \\
\hline D1 6433-48 & 12 & 1.65 & 152 & 2.72 & 1251 & 1.782 & 5400 & 8 & 80 & $13.3 \pm 1.3(79)$ \\
\hline D1 10314-34 & 20 & 1.45 & 90 & 1.65 & 513 & 1.783 & 5400 & 5 & 99 & $11.5 \pm 1.8(97)$ \\
\hline D1 11118-175 & 20 & 1.78 & 160 & 2.31 & 1040 & 1.781 & 5400 & 7 & 80 & $11.7 \pm 1.7(83)$ \\
\hline F1 9262-76 & 20 & 3.79 & 167 & 4.00 & 880 & 1.773 & 5400 & 12 & 96 & $12.2 \pm 1.5(100)$ \\
\hline F1 11142-162 & 20 & 1.50 & 87 & 2.96 & 859 & 1.750 & 5400 & 9 & 80 & $11.0 \pm 1.9(100)$ \\
\hline F1 12446-66 & 5 & 0.24 & 2 & 8.65 & 36 & 1.754 & 5400 & 3 & 75 & N.D. \\
\hline F1 14708-31 & 20 & 0.52 & 20 & 3.24 & 617 & 1.758 & 5400 & 10 & 80 & $8.9 \pm 3.6(13)$ \\
\hline F41-36 12080 & 15 & 0.51 & 19 & 2.82 & 524 & 1.728 & 5400 & 9 & 95 & $10.0 \pm 2.2(10)$ \\
\hline KCL 87-23 8532 & 20 & 3.05 & 183 & 3.02 & 905 & 1.764 & 5400 & 9 & 45 & $12.6 \pm 1.3(100)$ \\
\hline KCL 87-23 9365-94 & 20 & 2.94 & 147 & 2.79 & 698 & 1.764 & 5400 & 9 & 99 & $11.7 \pm 1.5(100)$ \\
\hline
\end{tabular}

${ }^{\mathrm{a}}$ zeta $=351 \pm 40$

and the muscovite detector was removed from the slides. The slides were etched in $48 \%$ hydrofluoric acid for 13 min to reveal induced fission tracks. The muscovite detectors from the glass standards and the age standards were etched in hydrofluoric acid for $45 \mathrm{~min}$ and $13 \mathrm{~min}$, respectively. Neutron fluxes for the reactor runs were determined from the age standards using the accepted ages of $27.9 \pm 0.7 \mathrm{Ma}$ for Fish Canyon Tuff, $22.8 \pm 0.5 \mathrm{Ma}$ for Mount Warning zircon, 98.7 $\pm 1.1 \mathrm{Ma}$ for Mount Dromedary apatite, and $31.4 \pm 0.5 \mathrm{Ma}$ for Durango apatite [Green, 1985]. The flux gradient was verified using the glass standards using the zeta calibration [Hurford and Green, 1983]. At least 15 to 20 apatite grains were examined in each sample when possible (Table A2).

[44] Since different apatite morphologies were noted in some samples, individual grain ages were calculated in order to determine whether one or more age populations were present. Individual grain ages were calculated using the formula of Price and Walker [1963]. The $\chi^{2}$ statistic was used to determine whether the individual ages belong to a single age population [Galbraith, 1981]. Mixed ages caused by partial

Table A3. Zircon Fission Track Raw Data ${ }^{a}$

\begin{tabular}{|c|c|c|c|c|c|c|c|c|}
\hline Sample & $\begin{array}{l}\text { No. } \\
\text { grains }\end{array}$ & $\begin{array}{c}\rho_{s} \times 10^{5} \\
\left(\mathrm{t} / \mathrm{cm}^{2}\right)\end{array}$ & $\mathrm{N}_{s}$ & $\begin{array}{c}\rho_{i} \times 10^{6} \\
\left(\mathrm{t} / \mathrm{cm}^{2}\right)\end{array}$ & $\begin{array}{c}\rho_{d} \times 10^{6} \\
\left(\mathrm{t} / \mathrm{cm}^{2}\right)\end{array}$ & $\mathrm{N}_{d}$ & $\begin{array}{c}\mathrm{U} \\
(\mathrm{ppm})\end{array}$ & $\begin{array}{c}\mathrm{P}\left(\chi^{2}\right) \\
(\%)\end{array}$ \\
\hline \multicolumn{9}{|c|}{ Surface Samples } \\
\hline PLC-8-89 & 20 & 2.85 & 1082 & 0.53 & 0.33419 & 4600 & 86 & 80 \\
\hline DK-1-89 & 20 & 6.22 & 1224 & 0.98 & 0.36125 & 4600 & 148 & $<1$ \\
\hline DK-6-89 & 20 & 6.67 & 1712 & 1.03 & 0.35294 & 4600 & 159 & $<1$ \\
\hline DK-12-89 & 4 & 1.37 & 213 & 0.26 & 0.34964 & 4600 & 41 & 55 \\
\hline \multicolumn{9}{|c|}{ Subsurface Samples } \\
\hline B1 9455-61 & 6 & 5.98 & 306 & 1.73 & 1.14115 & 4500 & 83 & $<1$ \\
\hline B1 12753-78 & 10 & 1.25 & 1370 & 1.79 & 1.1508 & 4500 & 85 & $<1$ \\
\hline D1 6433-48 & 20 & 5.28 & 2695 & 0.86 & 1.1587 & 4500 & 40 & $<1$ \\
\hline D1 11118-175 & 17 & 5.82 & 1927 & 1.22 & 1.15397 & 4500 & 58 & $<1$ \\
\hline F1 11142-162 & 20 & 5.69 & 1671 & 1.37 & 1.14007 & 4500 & 65 & $<1$ \\
\hline KCL 87-23 8532 & 5 & 9.07 & 544 & 2.23 & 1.12788 & 4600 & 108 & $<1$ \\
\hline
\end{tabular}

${ }^{\mathrm{a}}$ zeta $=351 \pm 40$. 


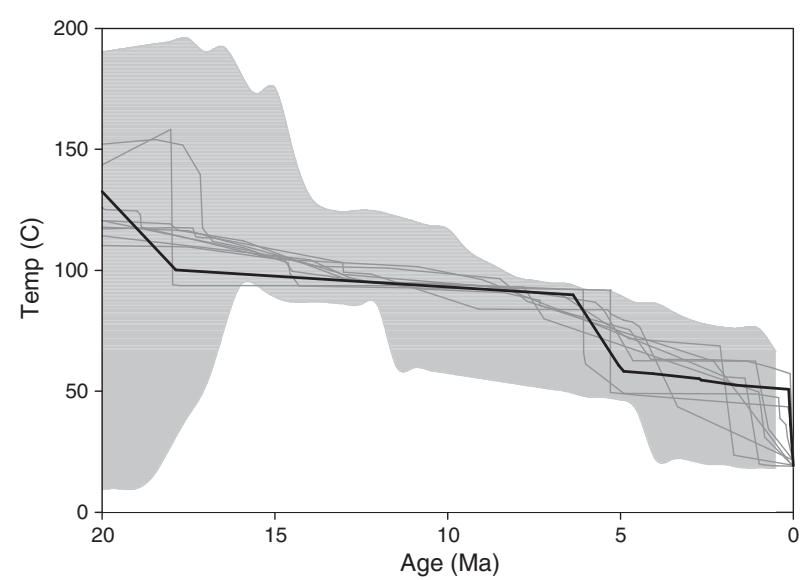

Figure A1. HeFTy model of sample DK-11-89, one of the structurally deepest samples, inverting apatite fission track lengths and (U-Th)/He to derive possible cooling paths. Black line - best fit cooling path; dark gray lines - good fit cooling paths; light gray swath - range of acceptable fit cooling paths. Best fit and good fit paths imply the onset of exhumation at $\sim 6 \mathrm{Ma}$.

annealing or by variations in provenance are indicated when the $\chi^{2}$ statistic does not pass at the $5 \%$ probability level. If the individual grain ages pass the $\chi^{2}$ test, then a conventional age estimate using the sum of the spontaneous and induced counts for all the grains is calculated, and the errors in the age are computed using the methods of Galbraith and Laslett [1985] and Galbraith [1984]. In cases where the sample fails the $\chi^{2}$ test, the mean grain age is more appropriate, since the failure indicates that the variation is greater than that due to Poisson counting error and a Gaussian component may be present.

[45] For samples containing abundant apatite, grain mounts for track-length studies were prepared as described previously. The mounts were examined with a microscope fitted with a 100 times oil immersion lens, a drawing tube, and a digitizing tablet. This system allows the track lengths to be measured to approximately $\pm 0.2 \mu \mathrm{m}$. Only confined tracks, those completely enclosed within the crystal, were measured (Table A2). Fission track length distributions from the deepest sample (DK-11-89) were modeled to invert for a thermal history using the software program HeFTy [Ketcham, 2005] (Figure A1). Since no kinetic parameters were available for these data, the fission track annealing model of Laslett et al. [1987] was applied, assuming constant initial fission track lengths of $16.3 \mu \mathrm{m}$. (U-Th)/He data from the nearby sample NNSE5 were used as added age constraints. Together, the inversion suggests the onset of exhumation at $\sim 6 \mathrm{Ma}$ (Figure A1).

[46] Acknowledgments. This work was funded by NSF grants EAR02229628 (J.A.S.) and EAR-0229317 (M.A.H.). We thank T. Gurer for field assistance and L. Hedges and K. Farley for (U-Th)/He sample preparation and analysis. B. Avdeev assisted with HeFTy modeling of apatite fission track data. J. Saleeby provided useful discussions on the geology of the plutonic and metamorphic rocks in the San Emigdio Mountains. Subsurface fission track samples are from wells that were operated by ARCO Western Energy. Surface fission track samples were collected by L. A. White and T. W. Dibblee, Jr. All fission track analyses were performed by S.A.K. under contract to ARCO Western Energy, now BP America, who graciously agreed to release these data for publication. The Wildlands Conservancy granted access to the Wind Wolves Preserve for work in the northern San Emigdio Mountains. Thoughtful and constructive reviews by Jeff Benowitz and Sarah Roeske are greatly appreciated.

\section{References}

Almgren, A. A., M. V. Filewicz, and H. L. Heitman (1988), Lower Tertiary foraminiferal and calcareous nannofossil zonation of California; an overview and recommendation, in Paleogene Stratigraphy, West Coast of North America, Field Trip Guidebook - Pacific Section, Society of Economic Paleontologists and Mineralogists, vol. 58, edited by M. V. Filewicz and R. L. Squires, pp. 83-106, Pacific Section SEPM (Society for Sedimentary Geology), Santa Barbara, Calif.

Anderson, R. S. (1990), Evolution of the northern Santa-Cruz Mountains by advection of crust past a San Andreas fault bend, Science, 249(4967), 397-401.

Ballance, P. F., D. G. Howell, and K. Ort (1983), Late Cenozoic wrench tectonics along the Nacimiento, South Cuyama, and La Panza faults, California, indicated by depositional history of the Simmler Formation, in Tectonics and Sedimentation Along Faults of the San Andreas System, edited by D. W. Anderson and M. J. Rymer, pp. 1-9, Soc. Econ. Paleontol. and Mineral., Pac. Sect., United States (USA).

Bawden, G. W., A. Donnellan, L. H. Kellogg, D. Dong, and J. B. Rundle (1997), Geodetic measurements of horizontal strain near the White Wolf Fault, Kern County, California, 1926-1993, J. Geophys. Res., 102(B3), 4957-4967.

Behr, W. M., and J. P. Platt (2012), Kinematic and thermal evolution during two-stage exhumation of a Mediterranean subduction complex, Tectonics, 31, TC4025, doi:10.1029/2012TC003121.

Benowitz, J. A., P. W. Layer, P. Armstrong, S. E. Perry, P. J. Haeussler, P. G. Fitzgerald, and S. VanLaningham (2011), Spatial variations in focused exhumation along a continental-scale strike-slip fault: The Denali fault of the eastern Alaska Range, Geosphere, 7(2), 455-467.

Benowitz, J. A., P. J. Haeussler, P. W. Layer, P. B. O’Sullivan, W. K. Wallace, and R. J. Gillis (2012), Cenozoic tectono-thermal history of the Tordrillo Mountains, Alaska; Paleocene-Eocene ridge subduction, decreasing relief, and late Neogene faulting, Geochem. Geophys. Geosyst., 13, Q04009, doi:10.1029/2011GC003951.

Benowitz, J. A., P. W. Layer, and S. Vanlaningham (2013), Persistent long-term (c. $24 \mathrm{Ma}$ ) exhumation in the eastern Alaska Range constrained by stacked thermochronology, in Advances in ${ }^{40} \mathrm{Ar} /{ }^{39}$ Ar Dating: From Archeology to Planetary Sciences, Spec. Publ. Geol. Soc. London, vol. 378, edited by F. Jourdan, D. F. Mark, and C. Verati, Geological Society of London, London, U. K., doi:10.1144/SP378.12.

Blythe, A. E., and N. Longinotti (2013), Exhumation of the southern Sierra Nevada-eastern Tehachapi Mountains constrained by low-temperature thermochronology: Implications for the initiation of the Garlock fault, Lithosphere, 5, 321-327.

Bohannon, R. G. (1976), Mid-Tertiary nonmarine rocks along the San Andreas fault in southern California, $\mathrm{PhD}$ thesis, 622 pp., University of California at Santa Barbara, Santa Barbara, CA.

Bohannon, R. G., and D. G. Howell (1982), Kinematic evolution of the junction of the San Andreas, Garlock, and Big Pine faults, California, Geology, 10(7), 358-363.

Bourne, S. J., T. Arnadottir, J. Beavan, D. J. Darby, P. C. England, B. Parsons, R. I. Walcott, and P. R. Wood (1998), Crustal deformation of the Marlborough fault zone in the South Island of New Zealand: Geodetic constraints over the interval 1982-1994, J. Geophys. Res., 103(B12), 30,147-30,165.

Bunds, M. P. (2001), Fault strength and transpressional tectonics along the Castle Mountain strike-slip fault, southern Alaska, Geol. Soc. Am. Bull., 113(7), 908-919.

Burbank, D. W., and D. P. Whistler (1987), Temporally constrained tectonic rotations derived from magnetostratigraphic data: Implications for the initiation of the Garlock Fault, California, Geology, 15(12), 1172-1175.

Bürgmann, R. (1991), Transpression along the southern San Andreas fault, Durmid Hill, California, Tectonics, 10(6), 1152-1163.

Bürgmann, R., P. Segall, R. Arrowsmith, and T. Dumitru (1994), Slip rates and earthquake hazard along the Foothills thrust belt in the southern Santa Cruz Mountains, California, Abstr. Programs Geol. Soc. Am., 26(7), 191.

Buscher, J. T., and J. A. Spotila (2007), Near-field response to transpression along the southern San Andreas fault, based on exhumation of the northern San Gabriel Mountains, southern California, Tectonics, 26, TC5004, doi:10.1029/2006TC002017.

Carman, M. F., Jr. (1964), Geology of the Lockwood Valley area Kern and Ventura counties, California, Spec. Rep. Calif. Div. Mines Geol., 81, 1-62.

Chapman, A. D., and J. B. Saleeby (2012), Geologic map of the San Emigdio Mountains, southern California, Geological Society of America Maps \& Charts, 101, scale 1:40,000, 3 p. text.

Chapman, A. D., S. Kidder, J. B. Saleeby, and M. N. Ducea (2010), Role of extrusion of the Rand and Sierra de Salinas schists in Late Cretaceous extension and rotation of the southern Sierra Nevada and vicinity, Tectonics, 29, TC5006, doi:10.1029/2006TC002017.

Chapman, A. D., P. I. Luffi, J. B. Saleeby, and S. Petersen (2011), Metamorphic evolution, partial melting and rapid exhumation above an 


\section{NIEMI ET AL.: EXHUMATION ALONG THE SAN ANDREAS FAULT}

ancient flat slab: Insights from the San Emigdio Schist, southern California, J. Metamorph. Geol., 29, 601-626.

Chapman, A. D., J. B. Saleeby, D. J. Wood, A. Piasecki, S. Kidder, M. N. Ducea, and K. A. Farley (2012), Late Cretaceous gravitational collapse of the southern Sierra Nevada batholith, California, Geosphere, 8(2), 314-341.

Clark, M. K., and R. Bilham (2008), Miocene rise of the Shillong Plateau and the beginning of the end for the eastern Himalaya, Earth Planet. Sci. Lett., 269(3-4), 336-350.

Clark, M. K., M. A. House, L. H. Royden, K. X. Whipple, B. C. Burchfiel, X. Zhang, and W. Tang (2005), Late Cenozoic uplift of southeastern Tibet, Geology, 33(6), 525-528.

Cole, R. B., and R. G. Stanley (1995), Middle Tertiary extension recorded by lacustrine fan-delta deposits, Plush Ranch basin, western Transverse Ranges, California, J. Sediment Res. B, 65(4), 455-468.

Corti, G., J. van Wijk, S. A. P. L. Cloetingh, and C. K. Morley (2007), Tectonic inheritance and continental rift architecture: Numerical and analogue models of the East African rift system, Tectonics, 26, TC6006, doi:10.1029/2006TC002086.

Cowgill, E., J. R. Arrowsmith, A. Yin, X. F. Wang, and Z. L. Chen (2004a), The Akato Tagh bend along the Altyn Tagh fault, northwest Tibet 2: Active deformation and the importance of transpression and strain hardening within the Altyn Tagh system, Geol. Soc. Am. Bull., 116(11-12), 1443-1464.

Cowgill, E., A. Yin, J. R. Arrowsmith, W. X. Feng, and S. H. Zhang (2004b), The Akato Tagh bend along the Altyn Tagh fault, northwest Tibet 1 : Smoothing by vertical-axis rotation and the effect of topographic stresses on bend-flanking faults, Geol. Soc. Am. Bull., 116(11-12), 1423-1442.

Critelli, S., and T. H. Nilsen (2000), Provenance and stratigraphy of the Eocene Tejon Formation, western Tehachapi Mountains, San Emigdio Mountains, and southern San Joaquin Basin, California, Sediment Geol., 136(1-2), 7-27.

Crowell, J. C., and J. W. R. Walker (1962), Anorthosite and related rocks along the San Andreas fault, southern California, Univ. Calif. Publ. Geol. Sci., 40, 219-288.

Cunningham, D. (2007), Structural and topographic characteristics of restraining bend mountain ranges of the Altai, Gobi Altai and easternmost Tien Shan, in Tectonics of Strike-Slip Restraining and Releasing Bends, edited by W. D. Cunningham and P. Mann, pp. 219-237, Geological Society of London, London.

Dair, L., and M. L. Cooke (2009), San Andreas fault geometry through the San Gorgonio Pass, California, Geology, 37(2), 119-122.

Darin, M. H., and R. Dorsey (2013), Reconciling disparate estimates of tota offset on the southern San Andreas fault, Geology, 41(9), 975-978, doi:10.1130/G34276.1.

Dart, R. L., M. N. Machette, D. Burns, G. D. Faneros, J. D. Little, and J. R. Davis (2000), Digital database of faults from the fault activity map of California and adjacent areas, CD-ROM 2000-006.

Davis, T. L. (1983), Late Cenozoic structure and tectonic history of the western "Big Bend" of the San Andreas fault and adjacent San Emigdio Mountains, $\mathrm{PhD}$ thesis, 580 pp., University of California at Santa Barbara, Santa Barbara, CA.

DeCelles, P. G. (1988), Middle Cenozoic depositional, tectonic, and sea level history of southern San Joaquin Basin, California, Am. Assoc. Petrol. Geol. Bull., 72(11), 1297-1322.

Dewey, J. F., R. E. Holdsworth, and R. A. Strachan (1998), Transpression and transtension zones, in Continental Transpressional and Transtensional Tectonics, vol. 135, edited by R. E. Holdsworth, R. A. Strachan, and J. F. Dewey, pp. 1-14, Geological Society, London, Special Publications.

Dibblee, T. W., Jr. (1961), Geologic structure of the San Emigdio Mountains, Kern County, California, in Geology and Paleontology of the Southern Border of the San Joaquin Valley, Kern County, California, Field trip Guidebook, edited by T. W. Dibblee Jr., pp. 2-28, Pacific Section, Society of Economic Paleontologists and Mineralogists, California

Dibblee, T. W., Jr. (1973), Geologic maps of the Santiago Creek, Eagle Rest Peak, Pleito Hills, Grapevine, and Pastoria Creek quadrangles, Kern County, California, U. S. Geological Survey Open-file Rep., 73-57, scale 1:1:24,000.

Dillon, J. T., and P. L. Ehlig (1993), Displacement on the southern San Andreas fault, in The San Andreas Fault System: Displacement, Palinspastic Reconstruction, and Geologic Evolution, Geological Society of America Memoir 178, edited by R. E. Powell, R. J. Weldon II, and J. C. Matti, pp. 199-216, Geological Society of America, Boulder, Colo.

Dokka, R. K., and C. J. Travis (1990), Role of the eastern California shear zone in accommodating Pacific-North American plate motion, Geophys. Res. Lett., 17(9), 1323-1326.

Dunbar, J. A., and D. S. Sawyer (1989), How preexisting weaknesses control the style of continental breakup, J. Geophys. Res., 94(B6), 7278-7292.

Ehlert, K. W. (2003), Tectonic significance of the middle Miocene Min Canyon and Caliente formations, southern California, in Evolution of Ridge Basin, Southern California: An Interplay of Sedimentation and Tectonics, edited by J. C. Crowell, pp. 113-130, Geological Society of America, Boulder, Colo.
Ehlig, P. L., K. W. Ehlert, and B. M. Crowe (1975), Offset of the upper Miocene Caliente and Mint Canyon formations along the San Gabriel and San Andreas faults, Spec. Rep. Calif. Div. Mines Geol., 118, 83-92.

Farley, K. A. (2000), Helium diffusion from apatite: General behavior as illustrated by Durango fluorapatite, J. Geophys. Res., 105(B2), 2903-2914.

Farley, K. A. (2002), (U-Th)/He dating: Techniques, calibrations, and applications, Rev. Mineral. Geochem., 47, 819-843.

Farley, K. A., and D. F. Stockli (2002), (U-Th)/He dating of phosphates: Apatite, monazite, and xenotime, Rev. Mineral. Geochem., 48, 559-577.

Farley, K. A., R. A. Wolf, and L. T. Silver (1996), The effects of long alphastopping distances on (U-Th)/He ages, Geochim. Cosmochim. Acta 60(21), 4223-4229.

Fitzgerald, P. G., M. Sandiford, P. J. Barrett, and A. J. W. Gleadow (1986), Asymmetric extension associated with uplift and subsidence in the Transantarctic Mountains and Ross Embayment, Earth Planet. Sci. Lett., 81(1), 67-78

Fitzgerald, P. G., E. Stump, and T. F. Redfield (1993), Late Cenozoic uplift of Denali and its relation to relative plate motion and fault morphology, Science, 259(5094), 497-499.

Flowers, R. M., D. L. Shuster, B. P. Wernicke, and K. A. Farley (2007), Radiation damage control on apatite $(\mathrm{U}-\mathrm{Th}) / \mathrm{He}$ dates from the Grand Canyon region, Colorado Plateau, Geology, 35(5), 447-450.

Fossen, H., and B. Tikoff (1998), Forward modeling of non-steady-state deformations and the "minimum strain path": Reply, J. Struct. Geol., 20(7), 979-981.

Foster, D. A., A. J. W. Gleadow, and G. Mortimer (1994), Rapid Pliocene exhumation in the Karakoram (Pakistan), revealed by fission-track thermochronology of the K2 gneiss, Geology, 22(1), 19-22.

Frizzell, V. A., Jr., and P. W. Weigand (1993), Whole-rock K-Ar ages and geochemical data from middle Cenozoic volcanic rocks, Southern California; A test of correlations across the San Andreas Fault, in The San Andreas Fault System: Displacement, Palinspastic Reconstruction and Geologic Evolution, edited by R. E. Powell, R. J. Weldon II, and J. C. Matti, pp. 273-287, Geological Society of America, Boulder, Colorado Frizzell, V. A., Jr., J. M. Mattinson, and J. C. Matti (1986), Distinctive Triassic megaporphyritic monzogranite: Evidence for only $160 \mathrm{~km}$ offset along the San Andreas fault, southern California, J. Geophys. Res., 91(B14), 14.

Galbraith, R. F. (1981), On statistical models for fission track counts, J. Int. Assoc. Math. Geol., 13(6), 471-478.

Galbraith, R. F. (1984), On statistical estimation in fission track dating, J. Int. Assoc. Math. Geol., 16(7), 653-669.

Galbraith, R. F., and G. M. Laslett (1985), Some remarks on statistical estimation in fission-track dating, Nucl. Tracks Radiat. Meas., 10(3), 361-363.

Gesch, D., O. Oimoen, S. Greenlee, C. Nelson, M. Steuck, and D. Tyler (2002), The National Elevation Dataset, Photogramm. Eng. Remote Sens., 68, 5-32.

Gleadow, A. J. W., and I. R. Duddy (1991), A natural long-term annealing experiment for apatite, Nucl. Tracks Radiat. Meas., 5, 169-174.

Goodman, E. D., and P. E. Malin (1992), Evolution of the southern San Joaquin Basin and mid-Tertiary "transitional" tectonics, central California, Tectonics, 11(3), 478-498.

Gradstein, F. M., J. G. Ogg, and A. G. Smith (Eds) (2004), A Geological Time Scale 2004, pp. 589, Cambridge Univ. Press, Cambridge, U. K.

Green, P. F. (1985), Comparison of zeta calibration baselines for fissiontrack dating of apatite, zircon and sphene, Chem. Geol., 58(1-2), 1-22.

Griscom, A., and R. C. Jachens (1990), Crustal and lithospheric structure from gravity and magnetic studies, in The San Andreas Fault System California, edited by R. E. Wallace, pp. 239-259, U. S. Geological Survey Professional Paper 1515, Washington, D. C

Guest, B., N. Niemi, and B. Wernicke (2007), Stateline fault system: A new component of the Miocene-Quaternary Eastern California shear zone Geol. Soc. Am. Bull., 119(11), 1337-1347.

Gutenberg, B. (1955), The first motion in longitudinal and transverse waves of the main shock and the direction of slip, in Earthquakes in Kern County, California, During 1952, edited by G. B. Oakeshott, pp. 165-170, California Division of Mines and Geology, Sacramento, Calif.

Hill, M. L., and T. W. Dibblee (1953), San Andreas, Garlock, and Big Pine faults, California-A study of the character, history, and tectonic significance of their displacements, Geol. Soc. Am. Bull., 64(4), 443-458.

Holbrook, W. S., and W. D. Mooney (1987), The crustal structure of the axis of the Great Valley, California, from seismic refraction measurements, Tectonophysics, 140(1), 49-63.

House, M. A., K. A. Farley, and D. Stockli (2000), Helium chronometry of apatite and titanite using Nd-YAG laser heating, Earth Planet. Sci. Lett. 183(3-4), 365-368.

House, M. A., B. P. Wernicke, and K. A. Farley (2001), Paleo-geomorphology of the Sierra Nevada, California, from (U-Th)/He ages in apatite, Am. J. Sci. 301(2), 77-102. 


\section{NIEMI ET AL.: EXHUMATION ALONG THE SAN ANDREAS FAULT}

Hurford, A. J., and P. F. Green (1983), The zeta age calibration of fissiontrack dating, Chem. Geol., 41(4), 285-317.

Hutton, K., J. Woessner, and E. Hauksson (2010), Earthquake monitoring in Southern California for seventy-seven years (1932-2008), Bull. Seismol. Soc. Am., 100(2), 423-446.

Jacobson, C. E., M. Grove, A. Vucic, J. N. Pedrick, and K. A. Ebert (2007), Exhumation of the Orocopia Schist and associated rocks of southeastern California: Relative roles of erosion, synsubduction tectonic denudation, and middle Cenozoic extension, in Convergent Margin Terranes and Associated Region: A Tribute to W. G. Ernst, edited by M. Cloos et al., pp. 1-37, Geological Society of America.

James, E. W. (1986), U/Pb age of the Antimony Peak Tonalite and its relation to Rand Schist in the San Emigdio Mountains, California, Abstr. Programs Geol. Soc. Am., 18(2), 121.

James, E. W., and J. M. Mattinson (1988), Metamorphic history of the Salinian Block: An isotopic reconnaissance, in Metamorphism and Crustal Evolution of the Western United States, edited by W. G. Ernst, pp. 938-952, Prentice-Hall, Englewood Cliffs, N. J.

Jennings, C. W. (1994), Fault activity map of California and adjacent areas with locations and ages of recent volcanic eruptions, Geologic Data Map, 6, scale 1:500000.

Keller, E. A., R. L. Zepeda, T. K. Rockwell, T. L. Ku, and W. S. Dinklage (1998), Active tectonics at Wheeler Ridge, southern San Joaquin Valley, California, Geol. Soc. Am. Bull., 110(3), 298-310.

Keller, E. A., D. B. Seaver, D. L. Laduzinsky, D. L. Johnson, and T. L. Ku (2000), Tectonic geomorphology of active folding over buried reverse faults: San Emigdio Mountain front, southern San Joaquin Valley, California, Geol. Soc. Am. Bull., 112(1), 86-97.

Kellogg, K. S. (1999), Geologic map of the Lockwood Valley quadrangle, Ventura County, California, U. S. Geol. Surv. Open File Rep., OF 99-0130, scale $1: 24000,8$ p. text

Kellogg, K. S. (2003), Geologic map of the Cuddy Valley quadrangle, Kern and Ventura Counties, California, U. S. Geol. Surv. Open File Rep., OF 03-0153, scale 1:24,000, 17 p. text.

Kellogg, K. S., and D. P. Miggins (2002), Geologic map of the Sawmil Mountain quadrangle, Kern and Ventura Counties, California, $U$. S Geol. Surv. Open File Rep., OF 02-406, scale 1:1:24,000.

Kellogg, K. S., and S. A. Minor (2005), Pliocene transpressional modification of depositional basins by convergent thrusting adjacent to the "Big Bend" of the San Andreas fault: An example from Lockwood Valley, Southern California, Tectonics, 24, TC1004, doi:10.1029/2003TC001610.

Kellogg, K. S., S. A. Minor, and P. M. Cossette (2008), Geologic map of the eastern three-quarters of the Cuyama $30^{\prime} \times 60^{\prime}$ quadrangle, California Scientific Investigations Map, 3002, scale 1:100,000.

Ketcham, R. A. (2005), Forward and inverse modeling of low-temperature thermochronometry data, Rev. Mineral. Geochem., 58, 275-314.

Kleinpell, R. M. (1938), Miocene Stratigraphy of California, pp. 450, American Association of Petroleum Geologists, Tulsa, Okla.

Lachenbruch, A. H., J. H. Sass, G. D. Clow, and R. Weldon (1995), Heat flow at Cajon Pass, California, revisited, J. Geophys. Res., 100(B2), 2005-2012.

Laslett, G. M., P. F. Green, I. R. Duddy, and A. J. W. Gleadow (1987), Thermal annealing of fission tracks in apatite, Chem. Geol., 65(1), 1-13.

Law, R. D., K. Eriksson, and C. Davisson (2001), Formation, evolution, and inversion of the middle Tertiary Diligencia basin, Orocopia Mountains, southern California, Geol. Soc. Am. Bull., 113(2), 196-221.

Lechler, A. R., and N. A. Niemi (2011), Sedimentologic and isotopic constraints on the Paleogene paleogeography and paleotopography of the southern Sierra Nevada, California, Geology, 39(4), 379-382.

Lindvall, S. C., T. K. Rockwell, T. E. Dawson, J. G. Helms, and K. W. Bowman (2002), Evidence for two surface ruptures in the past 500 years on the San Andreas fault at Frazier Mountain, California, Bull. Seismol. Soc. Am., 92(7), 2689-2703.

Magistrale, H., and C. Sanders (1996), Evidence from precise earthquake hypocenters for segmentation of the San Andreas fault in San Gorgonio Pass, J. Geophys. Res., 101(B2), 3031-3044.

Mahan, K. H., B. Guest, B. Wernicke, and N. A. Niemi (2009), Lowtemperature thermochronologic constraints on the kinematic history and spatial extent of the Eastern California shear zone, Geosphere, 5(6), 483-495.

Maheo, G., J. Saleeby, Z. Saleeby, and K. A. Farley (2009), Tectonic control on southern Sierra Nevada topography, California, Tectonics, 28, TC6006, doi:10.1029/2008TC002340.

Mallory, V. S. (1959), Lower Tertiary Biostratigraphy of the California Coast Ranges, vol. 416, American Association of Petroleum Geologists, Tulsa, Okla.

Matti, J. C., and D. M. Morton (1993), Paleogeographic evolution of the San Andreas fault in Southern California: A reconstruction based on a new cross-fault correlation, in The San Andreas Fault System: Displacement, Palinspastic Reconstruction, and Geologic Evolution, edited by R. E.
Powell, R. J. Weldon II, and J. C. Matti, pp. 107-159, Geological Society of America Memoir 178, Boulder, Colo.

McClay, K., and M. Bonora (2001), Analog models of restraining stepovers in strike-slip fault systems, Am. Assoc. Petrol. Geol. Bull., 85(2), 233-260. McDowell, F. W., W. C. McIntosh, and K. A. Farley (2005), A precise ${ }^{40} \mathrm{Ar} /{ }^{39}$ Ar reference age for the Durango apatite (U-Th)/He and fission-track dating standard, Chem. Geol., 214(3-4), 249-263.

McGill, J. T. (1951), Quaternary geology of the north-central San Emigdio Mountains, California, $\mathrm{PhD}$ thesis, $204 \mathrm{pp}$, University of California at Los Angeles, Los Angeles, Calif.

McGill, S. F., S. G. Wells, S. K. Fortner, H. A. Kuzma, and J. D. McGill (2009), Slip rate of the western Garlock fault, at Clark Wash, near Lone Tree Canyon, Mojave Desert, California, Geol. Soc. Am. Bull., 121, 536-554

Medwedeff, D. A. (1988), Structural analysis and tectonic significance of lateTertiary and Quaternary, compressive-growth folding, San Joaquin Valley, California, $\mathrm{PhD}$ thesis, 184 pp, Princeton University, Princeton, N. J.

Molnar, P. (1988), Continental tectonics in the aftermath of plate-tectonics, Nature, 335(6186), 131-137.

Molnar, P., and K. E. Dayem (2010), Major intracontinental strike-slip faults and contrasts in lithospheric strength, Geosphere, 6(4), 444-467.

Monastero, F. C., A. E. Sabin, and J. D. Walker (1997), Evidence for postearly Miocene initiation of movement on the Garlock fault from offset of the Cudahy Camp Formation, east-central California, Geology, 25(3), 247-250.

Mount, V. S., and J. Suppe (1987), State of stress near the San Andreas fault: Implications for wrench tectonics, Geology, 15(12), 1143-1146.

Mueller, K., and J. Suppe (1997), Growth of Wheeler Ridge anticline, California: Geomorphic evidence for fault-bend folding behaviour during earthquakes, J. Struct. Geol., 19(3-4), 383-396.

Mueller, K., and P. Talling (1997), Geomorphic evidence for tear faults accommodating lateral propagation of an active fault-bend fold, Wheeler Ridge, California, J. Struct. Geol., 19(3-4), 397-411.

Naeser, C. W. (1979), Fission-track dating and geologic annealing of fission tracks, in Lectures in Isotope Geology, edited by E. Jäger and J. C. Hunziker, pp. 154-169, Springer-Verlag, New York.

Naeser, C. W., and H. Faul (1969), Fission track annealing in apatite and sphene, J. Geophys. Res., 74(2), 705-710.

Namson, J. S., and T. L. Davis (1988a), Structural transect of the western Transverse Ranges, California: Implications for lithospheric kinematics and seismic risk evaluation, Geology, 16(8), 675-679.

Namson, J. S., and T. L. Davis (1988b), Seismically active fold and thrust belt in the San Joaquin Valley, central California, Geol. Soc. Am. Bull., $100(2), 257-273$

Niemi, N. A., B. P. Wernicke, R. J. Brady, J. B. Saleeby, and G. C. Dunne (2001), Distribution and provenance of the middle Miocene Eagle Mountain Formation, and implications for regional kinematic analysis of the Basin and Range province, Geol. Soc. Am. Bull., 113(4), 419-442.

Nilsen, T. H., T. W. Dibblee Jr., and W. O. Addicott (1973), Lower and middle Tertiary stratigraphic units of the San Emigdio and western Tehachapi Mountains California, U. S. Geol. Surv. Bull., 1372-H, H1-H23.

Nourse, J. A. (2002), Middle Miocene reconstruction of the central and eastern San Gabriel Mountains, Southern California, with implications for evolution of the San Gabriel Fault and Los Angeles Basin, in Contributions to Crustal Evolution of the Southwestern United States, edited by A. P. Barth, pp. 161-185, Geological Society of America, Boulder, Colo.

Odonne, F., and P. Vialon (1983), Analog models of folds above a wrench fault, Tectonophysics, 99(1), 31-46.

Oskin, M., and J. Stock (2003), Marine incursion synchronous with plateboundary localization in the Gulf of California, Geology, 31(1), 23-26.

Oskin, M., J. Stock, and A. Martin-Barajas (2001), Rapid localization of Pacific-North America plate motion in the Gulf of California, Geology, 29(5), 459-462.

Pickett, D. A., and J. B. Saleeby (1994), Nd, Sr, and Pb isotopic characteristics of Cretaceous intrusive rocks from deep levels of the Sierra Nevada batholith, Tehachapi Mountains, California, Contrib. Mineral. Petrol., $118(2), 198-215$

Powell, R. E. (1981), Geology of the crystalline basement complex, eastern Transverse Ranges, southern California: Constraints on regional tectonic interpretation, $\mathrm{PhD}$ thesis, $441 \mathrm{pp}$, California Institute of Technology, Pasadena, Calif.

Powell, R. E. (1993), Balanced palinspastic reconstruction of pre-late Cenozoic paleogeology, Southern California: Geologic and kinematic constraints on evolution of the San Andreas fault system, in The San Andreas Fault System: Displacement, Palinspastic Reconstruction, and Geologic Evolution, edited by R. E. Powell, R. J. Weldon II, and J. C. Matti, pp. 1-106, Geological Society of America, Boulder, Colo. Powell, R. E., and R. J. I. Weldon (1992), Evolution of the San Andreas fault, Annu. Rev. Earth Planet. Sci., 20, 431-468. 


\section{NIEMI ET AL.: EXHUMATION ALONG THE SAN ANDREAS FAULT}

Price, P. B., and R. M. Walker (1963), Fossil tracks of charged particles in mica and the age of minerals, J. Geophys. Res., 68(16), 4847-4862.

Prothero, D. R. (2001), Chronostratigraphic calibration of the Pacific Coast Cenozoic: A summary, in Book - Pacific Section, Society of Economic Paleontologists and Mineralogists, vol. 91, pp. 377-394, Tulsa, Okla.

Reiners, P. W., R. Brady, K. A. Farley, J. E. Fryxell, B. Wernicke, and D. Lux (2000), Helium and argon thermochronometry of the Gold Butte Block, South Virgin Mountains, Nevada, Earth Planet. Sci. Lett., 178(3-4), 315-326.

Rhoades, M. L., and P. G. DeCelles (1995), The provenance of middle Tertiary sandstones of the San Emigdio Range and Tehachapi Range, southern California, Am. Assoc. Petrol. Geol. Bull., 79(4), 596.

Richter, C. F. (1955), Foreshocks and aftershocks, in Earthquakes in Kern County California During 1952, edited by G. Oakeshott, pp. 177-198, California Division of Mines and Geology, San Francisco.

Ring, U. (1994), The influence of preexisting structure on the evolution of the Cenozoic Malawi Rift (East African rift system), Tectonics, 13(2), $313-326$.

Ross, D. C. (1972), Petrographic and chemical reconnaissance study of some granitic and gneissic rocks near the San Andreas fault from Bodega Head to Cajon Pass, California, U. S. Geol. Surv. Prof. Pap., 698, 92.

Ross, D. C. (1989), The metamorphic and plutonic rocks of the southernmost Sierra Nevada, California, and their tectonic framework, U. S. Geol. Surv. Prof. Pap., 1381, 159 p.

Rust, D. (1998), Contractional and extensional structures in the transpressive "Big Bend" of the San Andreas fault, southern California, in Continental Transpressional and Transtensional Tectonics, edited by R. E. Holdsworth, R. A. Strachan, and J. F. Dewey, pp. 119-126, Geological Society of London, London, U. K

Saleeby, J. B., D. B. Sams, and R. W. Kistler (1987), U/Pb zircon, strontium, and oxygen isotopic and geochronological study of the southernmost Sierra Nevada batholith, California, J. Geophys. Res., 92(B10), 10,443-10,466.

Saleeby, J., K. A. Farley, R. W. Kistler, and R. J. Fleck (2007), Thermal evolution and exhumation of deep-level batholithic exposures, southernmost Sierra Nevada, California, in Convergent Margin Terranes and Associated Region: A Tribute to W. G. Ernst, edited by M. Cloos et al., pp. 39-66, Geological Society of America.

Salyards, S. L. (1989), Dating and characterizing late Holocene earthquakes using paleomagnetics, $\mathrm{PhD}$ thesis, $434 \mathrm{pp}$, California Institute of Technology, Pasadena, CA, United States, (USA).

Sanderson, D. J., and W. R. D. Marchini (1984), Transpression, J. Struct Geol., 6(5), 449-458.

Sherkati, S., J. Letouzey, and D. Frizon de Lamotte (2006), Central Zagros foldthrust belt (Iran): New insights from seismic data, field observation, and sandbox modeling, Tectonics, 25, TC4007, doi:10.1029/2004TC001766.

Shuster, D. L., R. M. Flowers, and K. A. Farley (2006), The influence of natural radiation damage on helium diffusion kinetics in apatite, Earth Planet. Sci. Lett., 249(3-4), 148-161.

Sieh, K. E. (1978), Slip along the San Andreas fault associated with the great 1857 earthquake, Bull. Seismol. Soc. Am., 68(5), 1421-1447.

Sieh, K. E., and R. H. Jahns (1984), Holocene activity of the San Andreas fault at Wallace Creek, California, Geol. Soc. Am. Bull., 95(8), $883-896$.

Snow, J. K., and B. Wernicke (2000), Cenozoic tectonism in the centra Basin and Range: Magnitude, rate, and distribution of upper crustal strain, Am. J. Sci., 300(9), 659-719.

Spotila, J. A., and K. Sieh (2000), Architecture of transpressional thrust faulting in the San Bernardino Mountains, southern California, from deformation of a deeply weathered surface, Tectonics, 19(4), 589-615.

Spotila, J. A., K. A. Farley, and K. Sieh (1998), Uplift and erosion of the San Bernardino Mountains associated with transpression along the San Andreas fault California, as constrained by radiogenic helium thermochronometry, Tectonics, 17(3), 360-378.

Spotila, J. A., K. A. Farley, J. D. Yule, and P. W. Reiners (2001), Near-field transpressive deformation along the San Andreas fault zone in southern California, based on exhumation constrained by (U-Th)/He dating, J. Geophys. Res., 106(B12), 30,909-930,922.

Spotila, J. A., N. Niemi, R. Brady, M. House, J. Buscher, and M. Oskin (2007a), Long-term continental deformation associated with transpressive plate motion: The San Andreas fault, Geology, 35(11), 967-970.
Spotila, J. A., M. A. House, N. A. Niemi, R. C. Brady, M. Oskin, and J. T. Buscher (2007b), Patterns of bedrock uplift along the San Andreas fault and implications for mechanisms of transpression, in Exhumation Associated with Continental Strike-Slip Fault Systems, edited by S. M. Roeske et al., pp. 15-33, Geological Society of America, Boulder, Colo.

Stockli, D. F., K. A. Farley, and T. A. Dumitru (2000), Calibration of the apatite (U-Th)/He thermochronometer on an exhumed fault block, White Mountains, California, Geology, 28, 983-986.

Stüwe, K., L. White, and R. Brown (1994), The influence of eroding topography on steady-state isotherms; Application to fission track analysis, Earth Planet. Sci. Lett., 124(1-4), 63-74.

Suppe, J., and D. A. Medwedeff (1990), Geometry and kinematics of faultpropagation folding, Eclogae Geol. Helv., 83(3), 409-454.

Sylvester, A. G. (1988), Strike-slip faults, Geol. Soc. Am. Bull., 100(11), 1666-1703.

Tagami, T., A. Carter, and A. J. Hurford (1996), Natural long-term annealing of the zircon fission-track system in Vienna Basin deep borehole samples: Constraints upon the partial annealing zone and closure temperature, Chem. Geol., 130(1-2), 147-157.

Tennyson, M. E. (1989), Pre-transform early Miocene extension in western California, Geology, 17(9), 792-796.

Teyssier, C., B. Tikoff, and M. Markley (1995), Oblique plate motion and continental tectonics, Geology, 23(5), 447-450.

Teyssier, C., B. Tikoff, and J. Weber (2002), Attachment between brittle and ductile crust at wrenching plate boundaries, in Continental Collision and the Tectono-sedimentary Evolution of Forelands, edited by G. Bertotti, K. Schulmann, and S. Cloetingh, pp. 93-117, EGU.

Thomson, S. N. (2002), Late Cenozoic geomorphic and tectonic evolution of the Patagonian Andes between latitudes $42^{\circ} \mathrm{S}$ and $46^{\circ} \mathrm{S}$ : An appraisal based on fission-track results from the transpressional intra-arc LiquineOfqui fault zone, Geol. Soc. Am. Bull., 114(9), 1159-1173.

Tikoff, B., and C. Teyssier (1994), Strain modeling of displacement-field partitioning in transpressional orogens, J. Struct. Geol., 16(11), 1575-1588.

Tippett, J. M., and P. J. J. Kamp (1993), Fission track analysis of the late Cenozoic vertical kinematics of continental Pacific crust, South Island, New Zealand, J. Geophys. Res., 98(B9), 16,119-16,148.

Vauchez, A., and A. Nicolas (1991), Mountain building: strike-parallel motion and mantle anisotropy, Tectonophysics, 185(3-4), 183-201.

Vauchez, A., G. Barruol, and A. Tommasi (1997), Why do continents breakup parallel to ancient orogenic belts?, Terra Nova, 9(2), 62-66.

Wagner, G. A. (1968), Fission track dating of apatites, Earth Planet. Sci. Lett., 4(5), 411-415.

Wakabayashi, J., J. V. Hengesh, and T. L. Sawyer (2004), Four-dimensional transform fault processes: Progressive evolution of step-overs and bends, Tectonophysics, 392(1-4), 279-301.

White, L. A. (1992), Thermal and unroofing history of the western Transverse Ranges, California; results from apatite fission track thermochronology, $\mathrm{PhD}$ thesis, $574 \mathrm{pp}$, University of Texas at Austin, Austin, TX, United States, (USA).

White, L. A., S. A. Kelley, and J. D. Corrigan (1991), Thermal and structural history of the San Emigdio Mountains, southern San Joaquin Basin, California, based on fission-track analysis, Am. Assoc. Petrol. Geol. Bull., 75(3), 692.

Wilcox, R. E., T. P. Harding, and D. R. Seely (1973), Basic wrench tectonics, Am. Assoc. Petrol. Geol. Bull., 57(1), 74-96.

Woodcock, N. H., and M. Fischer (1986), Strike-slip duplexes, J. Struct. Geol., 8(7), 725-735.

Woodcock, N. H., and B. Rickards (2003), Transpressive duplex and flower structure; Dent fault system, NW England, J. Struct. Geol., 25(12), 1981-1992.

Woodcock, N. H., and C. Schubert (1994), Continental strike-slip tectonics, in Continental Deformation, edited by P. L. Hancock, pp. 251-263, Pergamon Press, Oxford.

Yeats, R. S. (1981), Quaternary flake tectonics of the California Transverse Ranges, Geology, 9(1), 16-20.

Yule, D., and K. Sieh (2003), Complexities of the San Andreas fault near San Gorgonio Pass: Implications for large earthquakes, J. Geophys. Res., 108(B11), 2548, doi:10.1029/2003JB002394

Zoback, M. D., et al. (1987), New evidence on the state of stress of the San Andreas fault system, Science, 238(4830), 1105-1111. 